\title{
Permafrost coverage, watershed area and season control of dissolved carbon and major elements in western Siberian rivers
}

\author{
O. S. Pokrovsky ${ }^{1}$, R. M. Manasypov ${ }^{2,3}$, S. Loiko ${ }^{2}$, L. S. Shirokova ${ }^{1,3}$, I. A. Krickov ${ }^{2}$, B. G. Pokrovsky ${ }^{4}$, \\ L. G. Kolesnichenko ${ }^{2}$, S. G. Kopysov ${ }^{2}$, V. A. Zemtzov ${ }^{2}$, S. P. Kulizhsky ${ }^{2}$, S. N. Vorobyev ${ }^{2}$, and S. N. Kirpotin ${ }^{2}$ \\ ${ }^{1}$ GET UMR 5563 CNRS, University of Toulouse, 14 Avenue Edouard Belin, 31400 Toulouse, France \\ ${ }^{2}$ BIO-GEO-CLIM Laboratory, Tomsk State University, Lenina av., 36, Tomsk, Russia \\ ${ }^{3}$ Institute of Ecological Problem of the North, 23 Nab Severnoi Dviny, RAS, Arkhangelsk, Russia \\ ${ }^{4}$ Geological Institute, Russian Academy of Science, Pyzhevskiy per., 7c1, Moscow, Russia \\ Correspondence to: O. S. Pokrovsky (oleg@get.obs-mip.fr)
}

Received: 1 June 2015 - Published in Biogeosciences Discuss.: 9 July 2015

Revised: 17 October 2015 - Accepted: 20 October 2015 - Published: 5 November 2015

\begin{abstract}
Analysis of organic and inorganic carbon (DOC and DIC, respectively), $\mathrm{pH}, \mathrm{Na}, \mathrm{K}, \mathrm{Ca}, \mathrm{Mg}, \mathrm{Cl}, \mathrm{SO}_{4}$ and $\mathrm{Si}$ in $\sim 100$ large and small rivers $\left(<10\right.$ to $\left.\leq 150000 \mathrm{~km}^{2}\right)$ of western Siberia sampled in winter, spring, and summer over a more than $1500 \mathrm{~km}$ latitudinal gradient allowed establishing main environmental factors controlling the transport of river dissolved components in this environmentally important region, comprising continuous, discontinuous, sporadic and permafrost-free zones. There was a significant latitudinal trend consisting in a general decrease in DOC, DIC, $\mathrm{SO}_{4}$, and major cation ( $\mathrm{Ca}, \mathrm{Mg}, \mathrm{Na}, \mathrm{K}$ ) concentration northward, reflecting the interplay between groundwater feeding (detectable mostly in the permafrost-free zone, south of $60^{\circ} \mathrm{N}$ ) and surface flux (in the permafrost-bearing zone). The northward decrease in concentration of inorganic components was strongly pronounced both in winter and spring, whereas for DOC, the trend of concentration decrease with latitude was absent in winter, and less pronounced in spring flood than in summer baseflow. The most significant decrease in $\mathrm{K}$ concentration from the southern $\left(<59^{\circ} \mathrm{N}\right)$ to the northern $(61-$ $67^{\circ} \mathrm{N}$ ) watersheds occurs in spring, during intense plant litter leaching. The latitudinal trends persisted for all river watershed size, from $<100$ to $>10000 \mathrm{~km}^{2}$. Environmental factors are ranked by their increasing effect on DOC, DIC, $\delta^{13} \mathrm{C}_{\mathrm{DIC}}$, and major elements in western Siberian rivers as follows: watershed area $<$ season $<$ latitude. Because the degree of the groundwater feeding is different between large and small rivers, we hypothesize that, in addition to groundwater feeding of the river, there was a significant role of
\end{abstract}

surface and shallow subsurface flow linked to plant litter degradation and peat leaching. We suggest that plant-litterand topsoil-derived DOC adsorbs on clay mineral horizons in the southern, permafrost-free and discontinuous/sporadic permafrost zone but lacks the interaction with minerals in the continuous permafrost zone. It can be anticipated that, under climate warming in western Siberia, the maximal change will occur in small ( $<1000 \mathrm{~km}^{2}$ watershed) rivers DOC, DIC and ionic composition and this change will be mostly pronounced in summer.

\section{Introduction}

The Western Siberian Lowland (WSL) can be considered as one of the most vulnerable permafrost-bearing territories with respect to ongoing climate change, due to (i) the dominance of discontinuous, sporadic and intermittent permafrost coverage rather than continuous and discontinuous permafrost of central and eastern Siberia and the Canadian High Arctic, (ii) its flat area and high impact of flooding and thermokarst development, and, most importantly, (iii) its high stock of ancient and recent organic carbon in the form of partially frozen peat deposits. Due to the importance of the boreal and subarctic continental zones in the Earth's carbon cycle and the high vulnerability of circumpolar zones to climate warming, the majority of conducted works have been devoted to the biogeochemistry of organic carbon and sediments in large rivers of the Russian boreal circumpolar 
zone (Gordeev et al., 1996, 2004; Moran and Woods, 1997; Lobbes et al., 2000; Dittmar and Kattner, 2003; Gebhardt et al., 2004; Cooper et al., 2008; Nikanorov et al., 2010a, b; Holmes et al., 2000, 2001, 2012; Pokrovsky et al., 2010; Feng et al., 2013). While these studies have allowed for the quantification of the carbon and major element delivery fluxes from the continent to the Arctic Ocean, the mechanisms responsible for carbon and metals mobilization from the soil/groundwater to the rivers remain very poorly understood. The WSL offers a unique site to test various hypotheses of element sources and to reveal related mechanisms as it presents the full gradient of the permafrost coverage, climate and vegetation over homogeneous sedimentary basement rock, essentially peat soil, flat orography and similar annual precipitation. Taking advantage of these features, in their pioneering studies, Frey et al. (2007a, b) and Frey and Smith (2005) provided a first-order assessment of the relative contributions of shallow surface water and deep groundwater to small western Siberian rivers. Their study was conducted during the summer baseflow season, presenting the largest contrast between permafrost-free and permafrostaffected rivers. This allowed them to conclude that climate warming should shift the permafrost-affected part of the region from surface feeding to groundwater feeding, while the permafrost-free zone may remain unaffected.

However, unlike many regions of the world, the boreal and subarctic river regions exhibit extreme seasonal variations in discharge and chemical elements concentrations (see Voronkov et al., 1966; Gordeev and Sidorov, 1993; Gordeev et al., 1996; Gislason et al., 1996; Gaillardet et al., 2003; Rember and Trefry, 2004; Zakharova et al., 2005, 2007; Bagard et al., 2011, 2013; Prokushkin et al., 2011; Guo et al., 2004b, 2007; Olefeldt and Roulet, 2012; Voss et al., 2015). The quantitative description of these systems, therefore, requires an understanding of how weathering rates and riverine fluxes of major and trace elements as well as their main carrier (organic carbon) vary seasonally. High seasonality implies significant variations in the source of the elements in river flow over the year, which is further accentuated by high variability in the depth of the active layer and relevant contributions of mineral soil weathering and the leaching of the soil organic horizon. As such, the chemistry of fluxes on the seasonal scale depends on the relative role of mineral dissolution vs. plant litter (organic soil) leaching. Although several recent studies have used isotopic techniques in an attempt to resolve the sources of elements in subarctic rivers (Engström et al., 2010; Keller et al., 2010; Pokrovsky et al., 2013a; Mavromatis et al., 2014), the relative contributions of mineral and plant litter/organic soil components remain poorly constrained, particularly for boreal watersheds.

The purpose of the present work is to improve our understanding of western Siberian river transport of organic and inorganic carbon and major elements $(\mathrm{Ca}, \mathrm{Mg}, \mathrm{K}, \mathrm{Si})$ via studying numerous watersheds across the $1500 \mathrm{~km}$ latitudinal profile during three main hydrological seasons: winter baseflow, spring flood and summer-autumn period (Zakharova et al., 2014). For a working hypothesis, we assume, following the previous works of Frey et al. (2007a, b), that the permafrost controls riverine chemical composition via regulating the degree of (i) groundwater feeding and (ii) leaching of elements from unfrozen (active) soil layers. Because groundwaters in the permafrost zone are discharged to the river via unfrozen taliks underneath the river bed (Anisimova, 1981; Bagard et al., 2011, 2013), it can be suggested that the impact of groundwaters via taliks will be mostly visible in large rivers, as is also known from the geocryological studies of the WSL (Fotiev, 1989, 1991). As a result, the contrast in groundwaterrelated element concentration between rivers of different latitude is expected to be the largest during winter baseflow. This is especially true in the WSL, exhibiting highly homogeneous, extremely flat topography and similar lithological cover (peat, sand and silt). Therefore, the first objective of this study was to test the effect of river size (watershed area) on inorganic river water components across the permafrost gradient. The second objective was to assess the effect of the permafrost coverage on DOC, DIC and its isotopic composition in rivers during different seasons. Specifically, during spring flood, when the majority of the soil layer is frozen, only surface flux should be important and the concentrations should reflect the degree of DOC and element leaching from the plant litter. The largest contrast between rivers of different size is therefore expected in August, whereas the spring flood should exhibit the lowest differences in terms of DOC transport by rivers of different climate and permafrost zones. Finally, the third objective of this study was firstorder assessment of the major river constituent concentration across the $2000 \mathrm{~km}$ latitudinal profile. Here, we expect in accordance with a general knowledge of DOC and major cation concentration and export fluxes dependence on temperature, vegetation and permafrost distribution (White and Blum, 1995; Dessert et al., 2003; Gaillardet et al., 2003; Millot et al., 2003; Oliva et al., 2003; Smedberg et al., 2006; Frey and McClelland, 2009; Prokushkin et al., 2011; Beaulieu et al., 2012; Tank et al., 2012a, b; Olefeldt et al., 2014) - a gradual or stepwise decrease in all river water constituents northward, from permafrost-free to discontinuous and continuous permafrost zone. Verifying the correctness of these research statements should allow for the quantitative prediction of the degree of river water composition modification in response to changing environmental conditions, notably the increase in the thickness of active (unfrozen) layer, increasing the winter discharge and augmenting plant biomass and productivity. 


\section{Study site and methods}

\subsection{Geographical setting}

The Western Siberian Lowland (WSL) is the world second largest flooding territory, after the Amazon's Varzea. The rivers (mainly the tributaries of the Ob, Pur, and Taz) drain Pleistocene sands and clays, covered by thick (1 to $3 \mathrm{~m}$ ) peat and enclosing three main zones of the boreal biome - taiga, forest-tundra and tundra. Approximate coverage of studied territory by sand, peat and clay deposits in the first $3 \mathrm{~m}$ soil layer is shown in Fig. 1. Note that the peat is always dominant on the watershed divides and bog zones, whereas the sand is abundant along the river valleys. Quaternary clays, sands, and silts ranging in thickness from several meters to 200-250 m have alluvial, lake-alluvial and, rarely, aeolian origin south of $60^{\circ} \mathrm{N}$ and fluvio-glacial and lake-glacial origin north of $60^{\circ} \mathrm{N}$. The older (i.e., Paleogene and Neogene) rocks are rarely exposed on the surface and are represented by sands, alevrolites and clays, where carbonate material is present as concretions of individual shells (Geological composition of the USSR, 1958). The climate is humid semi-continental with a mean annual temperature (MAT) ranging from $-0.5^{\circ} \mathrm{C}$ in the south (Tomsk region) to $-9.5^{\circ} \mathrm{C}$ in the north (Yamburg). The annual precipitation increases from $550 \mathrm{~mm}$ at the latitude of Tomsk to 650 $700 \mathrm{~mm}$ at Noyabrsk and further decreases to $600 \mathrm{~mm}$ at the lower reaches of the Taz River. The annual river runoff gradually increases northward, from $160-220 \mathrm{~mm} \mathrm{yr}^{-1}$ in the permafrost-free region to $280-320 \mathrm{~mm} \mathrm{yr}^{-1}$ in the Pur and Taz river basins located in the discontinuous to continuous permafrost zone (Nikitin and Zemtsov, 1986). A detailed description of physico-geography, hydrology, lithology and soil can be found in earlier works (Botch et al., 1995; Smith et al., 2004; Frey and Smith, 2005, 2007; Frey et al., 2007a, b; Beilman et al., 2009; Vorobyev et al., 2015) and in our recent limnological and pedological studies (Pokrovsky et al., 2013b; Shirokova et al., 2013; Manasypov et al., 2014, 2015; Stepanova et al., 2015). A detailed map of studied region together with main permafrost provenances and river runoff in the WSL is given in Fig. 1, and the list of sampled rivers grouped by watershed size and season is presented in Table 1 . Permafrost zonation in the WSL shown in this figure is based on extensive geocryological work in this region (Baulin et al., 1967; Gruzdov and Trofimov, 1980; Baulin, 1985; Liss et al., 2001). The hydrological parameters of the WSL rivers are described in Supplement S1.

\subsection{Chemical and isotope analyses and statistical treatment}

Altogether, 95 river samples were collected in early June 2013 (spring flood), August 2013 and 2014 (summer baseflow), October 2013 (autumn) and February 2014 (winter baseflow) along the $1500 \mathrm{~km}$ latitudinal gradient (Ta- ble 1). All sampled rivers of the WSL belong to the Kara Sea basin. Seasonal sampling covered a full gradient from south to north, except the month of October, which was sampled only in rivers south of $60^{\circ} \mathrm{N}$ (12 rivers in total). The watershed area of sampled rivers ranged from 2 to $150000 \mathrm{~km}^{2}$, not considering the $\mathrm{Ob}$ River in its medium course zone. Collected water samples were immediately filtered in prewashed $30 \mathrm{~mL}$ PP Nalgene ${ }^{\circledR}$ flasks through single-use Minisart filter units (Sartorius, acetate cellulose filter) with a diameter of $25 \mathrm{~mm}$ and a pore size of $0.45 \mu \mathrm{m}$. The first 20 to $50 \mathrm{~mL}$ of filtrate was discarded. Filtered solutions for cation analyses were acidified $(\mathrm{pH} \sim 2)$ with ultrapure double-distilled $\mathrm{HNO}_{3}$ and stored in pre-washed HDPE bottles. The preparation of bottles for sample storage was performed in a clean bench room (ISO A 10 000). Filtered samples for DOC, DIC, $\mathrm{UV}_{280 \mathrm{~nm}}$ absorbance and anions were stored in the refrigerator for a maximum of 3 weeks before the analyses. The effect of storage for DOC, DIC and optical measurements in boreal waters was found to be within the uncertainty of analysis (Ilina et al., 2014). Blanks were performed to control the level of pollution induced by sampling and filtration. The DOC blanks of filtrate never exceeded $0.1 \mathrm{mg} \mathrm{L}^{-1}$, which is quite low for the organic-rich river waters sampled in this study (i.e., $10-60 \mathrm{mg} \mathrm{L}^{-1} \mathrm{DOC}$ ). $\mathrm{pH}$ was measured in the field using a combined electrode calibrated against NIST buffer solutions ( $\mathrm{pH}$ of 4.00 and 6.86 at $25^{\circ} \mathrm{C}$ ). The accuracy of $\mathrm{pH}$ measurements was $\pm 0.02 \mathrm{pH}$ units. DOC and DIC were analyzed using a carbon total analyzer (Shimadzu TOC VSCN) with an uncertainty better than $3 \%$. Special calibration of the instrument for analysis of both form of dissolved carbon in organic-rich, DIC-poor waters was performed as described elsewhere (Prokushkin et al., 2011). Major anion $\left(\mathrm{Cl}, \mathrm{SO}_{4}\right)$ concentrations were measured by ion chromatography (HPLC, Dionex ICS 2000) with an uncertainty of $2 \%$. The UV absorbance at $280 \mathrm{~nm}$ is used as a proxy for aromatic C and source of DOM in the river water. It was measured using a $1 \mathrm{~cm}$ quartz cuvette in a CARY-50 UV-VIS spectrophotometer (Bruker, UK). Major cations $(\mathrm{Ca}, \mathrm{Mg}, \mathrm{Na}, \mathrm{K})$ and $\mathrm{Si}$ were determined with an ICP-MS Agilent ce 7500 with In and Re as internal standards and three various external standards, placed once per 10 samples of river water. Approximately $30 \%$ of samples were analyzed for $\mathrm{Ca}, \mathrm{Mg}$ and $\mathrm{Na}$ concentration using atomic absorption spectroscopy (flame) with an uncertainty of $2 \%$. Reasonable and non-systematic agreement (between 5 and $10 \%$ ) with the results of ICP MS analyses was achieved. Aqueous Si concentrations were also determined colorimetrically (molybdate blue method) with an uncertainty of $1 \%$ using a Technicon automated analyzer. The SLRS-5 (riverine water reference material for trace metals certified by the National Research Council of Canada) was used to check the accuracy and reproducibility of each analysis (Yeghicheyan et al., 2014).

The ${ }^{13} \mathrm{C}$ in dissolved inorganic carbon was analyzed in filtered river water sampled in bubble-free sealed glass bottles 
Table 1. List of sampled rivers, their watershed area and annual runoff. The codes under the months identify the sampling sites listed in Table S1 in the Supplement. The annual runoff was calculated following the approach of Frey et al. (2007b) as explained in Supplement 1.

\begin{tabular}{|c|c|c|c|c|c|c|c|c|c|}
\hline \multirow[t]{2}{*}{ Number on the map } & \multicolumn{4}{|c|}{ Season } & \multirow[t]{2}{*}{$\mathrm{N}$} & \multirow[t]{2}{*}{$\mathrm{E}$} & \multirow[t]{2}{*}{ River } & \multirow{2}{*}{$\begin{array}{r}\text { Watersheds, } \\
\mathrm{km}^{2}\end{array}$} & Annual runoff, \\
\hline & June & August & October & February & & & & & \\
\hline 1 & RJ-1 & & $\mathrm{R}-1$ & RF1 & $56^{\circ} 31^{\prime} 48^{\prime \prime}$ & $84^{\circ} 09^{\prime} 44^{\prime \prime}$ & $\mathrm{Ob}$ & 423100 & 207 \\
\hline 2 & RJ-3 & & $\mathrm{R}-3$ & $\mathrm{RF} 2$ & $56^{\circ} 46^{\prime} 19.5^{\prime \prime}$ & $83^{\circ} 57^{\prime} 35.7^{\prime \prime}$ & Prud & 61.5 & 44.8 \\
\hline 3 & RJ-2 & & $\mathrm{R}-2$ & & $56^{\circ} 43^{\prime} 15.0^{\prime \prime}$ & $83^{\circ} 55^{\prime} 35.1^{\prime \prime}$ & Chybyr' $^{\prime}$ & 8.14 & 44.8 \\
\hline 4 & RJ-4; R-10 & & R-4 & RF3 & $57^{\circ} 06^{\prime} 39.2^{\prime \prime}$ & $83^{\circ} 54^{\prime} 41.1^{\prime \prime}$ & Shegarka & 12000 & 58.3 \\
\hline 5 & RJ-5 & & $\mathrm{R}-5$ & RF4 & $57^{\circ} 19^{\prime} 20.7^{\prime \prime}$ & $83^{\circ} 55^{\prime} 53.8^{\prime \prime}$ & Brovka & 320 & 63.4 \\
\hline 6 & & BL-3 & & & $56^{\circ} 54^{\prime} 39.1^{\prime \prime}$ & $82^{\circ} 33^{\prime} 33.3^{\prime \prime}$ & Cherniy Klyuch & 32 & 168 \\
\hline 7 & & BL-2 & & & $57^{\circ} 02^{\prime} 23.75^{\prime \prime}$ & $82^{\circ} 04^{\prime} 02.44^{\prime \prime}$ & Bakchar & 3197 & 96.1 \\
\hline 8 & RJ-6 & & & RF5 & $57^{\circ} 36^{\prime} 43.3^{\prime \prime}$ & $83^{\circ} 37^{\prime} 02.1^{\prime \prime}$ & Malyi Tatosh & 302 & 63.4 \\
\hline 9 & RJ-7 & & $\mathrm{R}-7$ & RF6 & $57^{\circ} 37^{\prime} 17.3^{\prime \prime}$ & $83^{\circ} 31^{\prime} 53.3^{\prime \prime}$ & Bolshoy Tatosh & 1020 & 74.6 \\
\hline 10 & RJ-8 & & $\mathrm{R}-8$ & RF7 & $57^{\circ} 52^{\prime} 26.8^{\prime \prime}$ & $83^{\circ} 11^{\prime} 29.9^{\prime \prime}$ & Chemondaevka & 177 & 63.4 \\
\hline 11 & RJ-9 & & R-9 & RF8 & $57^{\circ} 58^{\prime} 45.7^{\prime \prime}$ & $82^{\circ} 58^{\prime} 32.2^{\prime \prime}$ & Sugotka & 275 & 63.4 \\
\hline 12 & $\mathrm{RJ}-10$ & RA-23 & & RF9 & $58^{\circ} 04^{\prime} 20.8^{\prime \prime}$ & $82^{\circ} 49^{\prime} 19.7^{\prime \prime}$ & Chaya & 27200 & 95.6 \\
\hline 13 & RJ-11 & & & RF10 & $58^{\circ} 23^{\prime} 16.8^{\prime \prime}$ & $82^{\circ} 11^{\prime} 39.0^{\prime \prime}$ & Tatarkin Istok & 58.6 & 33.4 \\
\hline 14 & RJ-12 & & $\mathrm{R}-12$ & & $58^{\circ} 24^{\prime} 38.0^{\prime \prime}$ & $82^{\circ} 08^{\prime} 46.0^{\prime \prime}$ & Istok & 12.3 & 127 \\
\hline 15 & $\mathrm{RJ}-13$ & RA-22 & $\mathrm{R}-13$ & RF11 & $58^{\circ} 26^{\prime} 06.9^{\prime \prime}$ & $82^{\circ} 05^{\prime} 43.6^{\prime \prime}$ & Shudelka & 3460 & 211 \\
\hline 16 & RJ-14 & & R-14 & $\mathrm{RF} 12$ & $58^{\circ} 33^{\prime} 03.1^{\prime \prime}$ & $81^{\circ} 48^{\prime} 44.3^{\prime \prime}$ & Chigas & 689 & 180 \\
\hline 17 & & BL-9 & & & $58^{\circ} 32^{\prime} 05.8^{\prime \prime}$ & $80^{\circ} 51^{\prime} 26.8^{\prime \prime}$ & Karza & 473 & 148 \\
\hline 18 & & BL-6 & & & $58^{\circ} 37^{\prime} 29.9^{\prime \prime}$ & $81^{\circ} 06^{\prime} 09.0^{\prime \prime}$ & Sochiga & 510 & 148 \\
\hline 19 & RJ-15 & RA-21; BL-4 & $\mathrm{R}-17$ & RF64 & $58^{\circ} 42^{\prime} 34.5^{\prime \prime}$ & $81^{\circ} 22^{\prime} 22.0^{\prime \prime}$ & Parabel & 25500 & 131 \\
\hline 20 & RJ-58 & BL-5 & $\mathrm{R}-15$ & RF65 & $58^{\circ} 40^{\prime} 46.5^{\prime \prime}$ & $84^{\circ} 27^{\prime} 56.6^{\prime \prime}$ & Vyalovka & 117 & 127 \\
\hline 21 & & & & RF63 & $58^{\circ} 59^{\prime} 37^{\prime \prime}$ & $80^{\circ} 34^{\prime} 00^{\prime \prime}$ & Vasyugan & 63780 & 177 \\
\hline 22 & & & & RF62 & $59^{\circ} 41^{\prime} 01.6^{\prime \prime}$ & $77^{\circ} 44^{\prime} 33.9^{\prime \prime}$ & Kornilovskaya & 190 & 133 \\
\hline 23 & & & & RF61 & $59^{\circ} 44^{\prime} 09.2^{\prime \prime}$ & $77^{\circ} 26^{\prime} 06^{\prime \prime}$ & Levyi Il'yas & 253 & 133 \\
\hline 24 & & & & RF60 & $60^{\circ} 08^{\prime} 43^{\prime \prime}$ & $77^{\circ} 16^{\prime} 53^{\prime \prime}$ & Koltogorka & 220 & 155.4 \\
\hline 25 & & & & RF58 & $60^{\circ} 30^{\prime} 19^{\prime \prime}$ & $76^{\circ} 58^{\prime} 57^{\prime \prime}$ & Sosninskii Yegan & 732 & 199 \\
\hline 26 & RJ-16 & BL-36 & & & $60^{\circ} 40^{\prime} 28.8^{\prime \prime}$ & $77^{\circ} 31^{\prime} 29.4^{\prime \prime}$ & $\mathrm{Ob}$ & 773200 & 216 \\
\hline 27 & & BL-35 & & & $60^{\circ} 44^{\prime} 10.9^{\prime \prime}$ & $77^{\circ} 22^{\prime} 55.9^{\prime \prime}$ & Medvedka & 7 & 173 \\
\hline 28 & & BL-34 & & & $60^{\circ} 45^{\prime} 58.5^{\prime \prime}$ & $77^{\circ} 26^{\prime} 12.6^{\prime \prime}$ & Saim & 26 & 173 \\
\hline 29 & & BL-33 & & & $60^{\circ} 47^{\prime} 29.3^{\prime \prime}$ & $77^{\circ} 19^{\prime} 13.5^{\prime \prime}$ & Mishkin Saim & 32 & 173 \\
\hline 30 & & BL-32 & & & $60^{\circ} 49^{\prime} 32.3^{\prime \prime}$ & $77^{\circ} 1346.3^{\prime \prime}$ & Alenkin Egan & 44 & 173 \\
\hline 31 & & BL-31 & & & $60^{\circ} 50^{\prime} 43.6^{\prime \prime}$ & $77^{\circ} 05^{\prime} 03.0^{\prime \prime}$ & Kaima & 31 & 173 \\
\hline 32 & & BL-30 & & & $60^{\circ} 55^{\prime} 41.0^{\prime \prime}$ & $76^{\circ} 53^{\prime} 49.3^{\prime \prime}$ & Vakh & 75090 & 298 \\
\hline 33 & RJ-23 & & & RF53 & $61^{\circ} 34^{\prime} 27.4^{\prime \prime}$ & $77^{\circ} 46^{\prime} 35.4^{\prime \prime}$ & Mokhovaya & 1260 & 192.3 \\
\hline 34 & RJ-17 & BL-29; RA-20 & & RF57 & $61^{\circ} 11^{\prime} 52.7^{\prime \prime}$ & $75^{\circ} 25^{\prime} 20.2^{\prime \prime}$ & Vatinsky Egan & 3190 & 287 \\
\hline 35 & & BL-28 & & & $61^{\circ} 12^{\prime} 19.5^{\prime \prime}$ & $75^{\circ} 23^{\prime} 06.5^{\prime \prime}$ & Er-Yakh & 9.35 & 173 \\
\hline 36 & RJ-18 & RA-19; BL-27 & & & $61^{\circ} 19^{\prime} 41.2^{\prime \prime}$ & $75^{\circ} 04^{\prime} 0.3^{\prime \prime}$ & Ur'evskii Egan & 359 & 272 \\
\hline 37 & RJ-19; R-9 & BL-26 & & RF56 & $61^{\circ} 26^{\prime} 13.6^{\prime \prime}$ & $74^{\circ} 47^{\prime} 39.7^{\prime \prime}$ & Agan & 27600 & 291 \\
\hline 38 & RJ-20 & RA-18 & & RF55 & $61^{\circ} 27^{\prime} 17.3^{\prime \prime}$ & $74^{\circ} 40^{\prime} 23.3^{\prime \prime}$ & Kottym'egan & 7.18 & 192 \\
\hline 40 & RJ-21 & & & RF54 & $61^{\circ} 29^{\prime} 46.6^{\prime \prime}$ & $74^{\circ} 15^{\prime} 30.3^{\prime \prime}$ & Segut-Yagun & 3.37 & 192 \\
\hline 41 & $\mathrm{RJ}-22$ & & & RF13 & $61^{\circ} 29^{\prime} 11.1^{\prime \prime}$ & $74^{\circ} 09^{\prime} 42.9^{\prime \prime}$ & Vach-Yagun & 1.79 & 192 \\
\hline 42 & RJ-24 & & & RF52 & $61^{\circ} 50^{\prime} 28.6^{\prime \prime}$ & $70^{\circ} 50^{\prime} 28.2^{\prime \prime}$ & Vachinguriyagun & 9.52 & 192 \\
\hline 43 & RJ -25 & & & RF14 & $61^{\circ} 58^{\prime} 05.1^{\prime \prime}$ & $73^{\circ} 47^{\prime} 03.4^{\prime \prime}$ & Lyukh-Yagun & 21.6 & 192 \\
\hline 44 & & & & RF51 & $61^{\circ} 59^{\prime} 39^{\prime \prime}$ & $73^{\circ} 47^{\prime} 39^{\prime \prime}$ & Limpas & 1648 & 320 \\
\hline 45 & RJ-26; R-7; R-8 & RA-17 & & RF50 & $62^{\circ} 07^{\prime} 50.0^{\prime \prime}$ & $73^{\circ} 44^{\prime} 05.6^{\prime \prime}$ & Òromyegan & 10770 & 263 \\
\hline 46 & RJ-57 & & & RF49 & $62^{\circ} 33^{\prime} 39.8^{\prime \prime}$ & $74^{\circ} 00^{\prime} 29.5^{\prime \prime}$ & Pintyr'yagun & 33.5 & 192 \\
\hline 47 & RJ-56 & BL-25 & & RF48 & $62^{\circ} 37^{\prime} 08.4^{\prime \prime}$ & $74^{\circ} 10^{\prime} 15.9^{\prime \prime}$ & Petriyagun & 9.65 & 192 \\
\hline 48 & RJ-54; R-6 & BL-24 & & RF47 & $63^{\circ} 38^{\prime} 23.4^{\prime \prime}$ & $74^{\circ} 10^{\prime} 52^{\prime \prime}$ & Kirill-Vys'yagun & 598 & 225 \\
\hline 49 & RJ-55 & BL-23 & & RF46 & $62^{\circ} 43^{\prime} 09.9^{\prime \prime}$ & $74^{\circ} 13^{\prime} 45.9^{\prime \prime}$ & Ai-Kirill-Vys'yagun & 24.0 & 192 \\
\hline 50 & & BL-22 & & RF45 & $63^{\circ} 11^{\prime} 19.3^{\prime \prime}$ & $74^{\circ} 36^{\prime} 25.5^{\prime \prime}$ & Pyrya-Yakha & 82 & 194 \\
\hline 51 & & RA-14 & & & $63^{\circ} 11^{\prime} 40.68^{\prime \prime}$ & $74^{\circ} 38^{\prime} 16.92^{\prime \prime}$ & Itu-Yakha & 250 & 194 \\
\hline 52 & & RA-13 & & & $63^{\circ} 10^{\prime} 3.48^{\prime \prime}$ & $74^{\circ} 45^{\prime} 16.32^{\prime \prime}$ & Nekhtyn-Pryn & 96 & 194 \\
\hline 53 & & RA-4 & & & $63^{\circ} 10^{\prime} 4.68^{\prime \prime}$ & $76^{\circ} 28^{\prime} 19.08^{\prime \prime}$ & Nyudya-Pidya-Yakha & 79.5 & 194 \\
\hline 54 & & RA-12 & & & $63^{\circ} 9^{\prime} 31.38^{\prime \prime}$ & $75^{\circ} 3^{\prime} 2.58^{\prime \prime}$ & Ponto-Yakha & 19 & 194 \\
\hline 55 & & RA-11 & & & $63^{\circ} 9^{\prime} 39.84^{\prime \prime}$ & $75^{\circ} 09^{\prime} 10.86^{\prime \prime}$ & Velykh-Pelykh-Yakha & 170 & 194 \\
\hline 56 & & RA-10 & & & $63^{\circ} 13^{\prime} 12.06^{\prime \prime}$ & $75^{\circ} 38^{\prime} 52.26^{\prime \prime}$ & Yangayakha & 88 & 194 \\
\hline 57 & & RA-9 & & & $63^{\circ} 13^{\prime} 25.2^{\prime \prime}$ & $76^{\circ} 5^{\prime} 23.04^{\prime \prime}$ & Tlyatsayakha & 43 & 194 \\
\hline 58 & & RA-8 & & & $63^{\circ} 13^{\prime} 3.66^{\prime \prime}$ & $76^{\circ} 15^{\prime} 24.6^{\prime \prime}$ & Chukusamal & 121 & 194 \\
\hline 59 & & RA-3; RA-7 & & & $63^{\circ} 46^{\prime} 22.92^{\prime \prime}$ & $76^{\circ} 25^{\prime} 28.86^{\prime \prime}$ & Vyngapur & 1979 & 324 \\
\hline 60 & & RA-6 & & & $63^{\circ} 12^{\prime} 43.38^{\prime \prime}$ & $76^{\circ} 21^{\prime} 27.66^{\prime \prime}$ & Goensapur & 11 & 194 \\
\hline 61 & & RA-5 & & & $63^{\circ} 12^{\prime} 45.96^{\prime \prime}$ & $76^{\circ} 24^{\prime} 1.32^{\prime \prime}$ & Denna & 15 & 194 \\
\hline 62 & & RA-15 & & & $63^{\circ} 8^{\prime} 34.02^{\prime \prime}$ & $74^{\circ} 54^{\prime} 29.1^{\prime \prime}$ & Nyudya-Itu-Yakha & 32 & 194 \\
\hline 63 & RJ-53; R-5 & RA-16; BL-21 & & RF38 & $63^{\circ} 22^{\prime} 01.6^{\prime \prime}$ & $74^{\circ} 31^{\prime} 53.2^{\prime \prime}$ & Kamgayakha & 175 & 194 \\
\hline 64 & RJ-52; $\quad$ R-4 & BL-19 & & RF39 & $63^{\circ} 36^{\prime} 48.2^{\prime \prime}$ & $74^{\circ} 35^{\prime} 28.6^{\prime \prime}$ & Khatytayakha & 34.6 & 194 \\
\hline 65 & RJ-51 & BL-18 & & RF40 & $63^{\circ} 40^{\prime} 41.8^{\prime \prime}$ & $74^{\circ} 35^{\prime} 20.7^{\prime \prime}$ & Pulpuyakha & 281 & 194 \\
\hline 66 & RJ-50; R-3 & BL-17 & & RF41 & $63^{\circ} 49^{\prime} 58.0^{\prime \prime}$ & $74^{\circ} 39^{\prime} 02.5^{\prime \prime}$ & Khanupiyakha & 74 & 194 \\
\hline 67 & RJ-29; R-2 & BL-16 & & RF42; RF37 & $63^{\circ} 51^{\prime} 23.4^{\prime \prime}$ & $75^{\circ} 08^{\prime} 05.6^{\prime \prime}$ & Kharucheiyakha & 820 & 292 \\
\hline 68 & $\mathrm{R}-1 ; \mathrm{Z}-55 ; \mathrm{RJ}-28$ & BL-20; RA-2; BL-15 & & RF43 & $63^{\circ} 49^{\prime} 54.2^{\prime \prime}$ & $75^{\circ} 22^{\prime} 47.1^{\prime \prime}$ & Pyakupur & 9880 & 324 \\
\hline 69 & RJ-27; $\quad$ Z-86 & BL-14; RA-1 & & RF44 & $63^{\circ} 47^{\prime} 04.5^{\prime \prime}$ & $75^{\circ} 37^{\prime} 06.8^{\prime \prime}$ & Lymbyd'yakha & 115 & 194 \\
\hline 70 & & BL-13 & & & $63^{\circ} 43^{\prime} 37.9^{\prime \prime}$ & $75^{\circ} 59^{\prime} 04.1^{\prime \prime}$ & Chuchi-Yakha & 1396 & 292 \\
\hline 71 & RJ-32 & & & & $64^{\circ} 12^{\prime} 08.4^{\prime \prime}$ & $75^{\circ} 24^{\prime} 28.4^{\prime \prime}$ & Ngarka-Tyde-Yakha & 59.9 & 186 \\
\hline 72 & RJ-30 & & & RF36 & $64^{\circ} 06^{\prime} 50.7^{\prime \prime}$ & $75^{\circ} 14^{\prime} 17.3^{\prime \prime}$ & Ngarka-Varka-Yakha & 67.1 & 186 \\
\hline 73 & RJ-31 & & & & $64^{\circ} 09^{\prime} 06.4^{\prime \prime}$ & $75^{\circ} 22^{\prime} 18.1^{\prime \prime}$ & Apoku-Yakha & 18.8 & 186 \\
\hline 74 & RJ-33 & RY $14-49$ & & RF35 & $64^{\circ} 17^{\prime} 31.9^{\prime \prime}$ & $75^{\circ} 44^{\prime} 33.4^{\prime \prime}$ & Etu-Yakha & 71.6 & 186 \\
\hline 75 & RJ-34 & & & & $64^{\circ} 19^{\prime} 10.1^{\prime \prime}$ & $76^{\circ} 08^{\prime} 26.7^{\prime \prime}$ & Varka-Yakha & 105 & 186 \\
\hline
\end{tabular}


Table 1. Continued.

\begin{tabular}{|c|c|c|c|c|c|c|c|c|c|}
\hline \multirow[t]{2}{*}{ Number on the map } & \multicolumn{4}{|c|}{ Season } & \multirow[t]{2}{*}{$\mathrm{N}$} & \multirow[t]{2}{*}{$\mathrm{E}$} & \multirow[t]{2}{*}{ River } & \multirow{2}{*}{$\begin{array}{r}\text { Watersheds, } \\
\mathrm{km}^{2}\end{array}$} & \multirow{2}{*}{$\begin{array}{l}\text { Annual runoff, } \\
\qquad \mathrm{mm} \mathrm{yr}^{-1}\end{array}$} \\
\hline & June & August & October & February & & & & & \\
\hline 76 & & RY $14-48$ & & & $64^{\circ} 23^{\prime} 30.6^{\prime \prime}$ & $76^{\circ} 19^{\prime} 50.1^{\prime \prime}$ & Khaloku-Yakha & 53 & 186 \\
\hline 77 & RJ-35 & & & RF34 & $64^{\circ} 26^{\prime} 05.2^{\prime \prime}$ & $76^{\circ} 24^{\prime} 37.0^{\prime \prime}$ & Kharv'-Yakha & 46.4 & 186 \\
\hline 78 & RJ-36 & RY 14-47 & & RF33 & $64^{\circ} 32^{\prime} 07.9^{\prime \prime}$ & $76^{\circ} 54^{\prime} 21.3^{\prime \prime}$ & Seryareyakha & 15.2 & 186 \\
\hline 79 & RJ-37 & RY $14-46$ & & RF32 & $64^{\circ} 40^{\prime} 14.0^{\prime \prime}$ & $77^{\circ} 05^{\prime} 27.2^{\prime \prime}$ & Purpe & 5110 & 309 \\
\hline 80 & RJ-38 & & & & $64^{\circ} 55^{\prime} 55.1^{\prime \prime}$ & $77^{\circ} 56^{\prime} 08.2^{\prime \prime}$ & Aivasedapur & 26100 & 309 \\
\hline 81 & RJ-39 & & & RF31 & $65^{\circ} 06^{\prime} 48.8^{\prime \prime}$ & $77^{\circ} 47^{\prime} 58.8^{\prime \prime}$ & Tydylyakha & 7.46 & 185 \\
\hline 82 & RJ-40 & RY 14-45 & & RF30 & $65^{\circ} 12^{\prime} 17.6^{\prime \prime}$ & $77^{\circ} 43^{\prime} 49.8^{\prime \prime}$ & Tydyotta & 12.0 & 309 \\
\hline 83 & RJ-41 & RY 14-44 & & RF29 & $65^{\circ} 23^{\prime} 34.1^{\prime \prime}$ & $77^{\circ} 45^{\prime} 46.7^{\prime \prime}$ & Ponie-Yakha & 78.9 & 185 \\
\hline 84 & RJ-42 & RY $14-43$ & & RF28 & $65^{\circ} 41^{\prime} 51.1^{\prime \prime}$ & $78^{\circ} 01^{\prime} 05.0^{\prime \prime}$ & Yamsovey & 4030 & 309 \\
\hline 85 & & RY $14-42$ & & & $65^{\circ} 46^{\prime} 34.5^{\prime \prime}$ & $78^{\circ} 08^{\prime} 25.8^{\prime \prime}$ & Khiroyakha & 183 & 185 \\
\hline 86 & RJ-43 & & & RF27 & $65^{\circ} 47^{\prime} 48.6^{\prime \prime}$ & $78^{\circ} 10^{\prime} 09.0^{\prime \prime}$ & Almayakha & 106 & 185 \\
\hline 87 & RJ-45 & & & RF25 & $65^{\circ} 58^{\prime} 54^{\prime \prime}$ & $77^{\circ} 34^{\prime} 05^{\prime \prime}$ & Yude-Yakha & 42.4 & 185 \\
\hline 88 & RJ-46 & & & RF26 & $65^{\circ} 59^{\prime} 05.7^{\prime \prime}$ & $77^{\circ} 40^{\prime} 52.6^{\prime \prime}$ & Tadym-Yakha & 39.9 & 185 \\
\hline 89 & RJ-44 & RY 14-41 & & & $65^{\circ} 57^{\prime} 05.5^{\prime \prime}$ & $78^{\circ} 18^{\prime} 59.1^{\prime \prime}$ & Pur & 112000 & 298 \\
\hline 90 & RJ-49 & RT2 14-32 & & & $65^{\circ} 59^{\prime} 14.7^{\prime \prime}$ & $78^{\circ} 32^{\prime} 25.2^{\prime \prime}$ & Malaya Khadyr-Yakha & 512 & 278 \\
\hline 91 & RJ-48 & RT2 14-31 & & & $66^{\circ} 17^{\prime} 10.8^{\prime \prime}$ & $79^{\circ} 15^{\prime} 06.1^{\prime \prime}$ & Ngarka Khadyta-Yakha & 1970 & 277 \\
\hline 92 & & RT2 14-30 & & & $66^{\circ} 59^{\prime} 20,9^{\prime \prime}$ & $79^{\circ} 22^{\prime} 30.5^{\prime \prime}$ & Malokha Yakha & 157 & 208 \\
\hline 93 & & RT2 14-29 & & & $67^{\circ} 10^{\prime} 54.8^{\prime \prime}$ & $78^{\circ} 51^{\prime} 04.5^{\prime \prime}$ & Nuny-Yakha & 656 & 312 \\
\hline 94 & RJ-47 & RT2 14-40 & & & $67^{\circ} 22^{\prime} 13.28^{\prime \prime}$ & $79^{\circ} 00^{\prime} 25.9^{\prime \prime}$ & Taz & 150000 & 330 \\
\hline 95 & & & & RF21 & $67^{\circ} 24^{\prime} 39^{\prime \prime}$ & $76^{\circ} 21^{\prime} 12^{\prime \prime}$ & Khadutte & 5190 & 346 \\
\hline
\end{tabular}

by gas chromatography and isotope mass spectrometry, using Delta V Advantage and Finnigan GasBench II in order to determine $\delta^{13} \mathrm{C}_{\text {DIC }}$ (per mil relative to V-PDB; Fritz and Fontes, 1980). For these measurements, $0.1 \mathrm{mg}$ of $100 \% \mathrm{H}_{3} \mathrm{PO}_{4}$ was added to the borosilicate vial and flushed with $\mathrm{He}$ (purity of 7.0) for $400 \mathrm{~s}$. Afterwards, $1 \mathrm{~mL}$ of the sample was injected into the vial and shaken for $36 \mathrm{~h}$ at $24^{\circ} \mathrm{C}$. Standard samples of C-O-1 and NBS-19 were routinely analyzed to test the accuracy of our measurements; typically, a disagreement of less than $0.3 \%$ o between the measured and certified values was observed, with a total estimated measurement uncertainty of $\pm 0.2 \%$.

The concentration of carbon and major elements in rivers were treated using the least-squares method, Pearson correlation and one-way ANOVA (SigmaPlot version 11.0, Systat Software, Inc.). The ANOVA was used to reveal the differences between different permafrost zones. It was carried out using Dunn's method because each sampling period contained a different number of rivers. Regressions and power functions were used to examine the relationships between the dissolved component concentrations and the watershed area, river discharge, average latitude of the watershed and seasons. Comparison of DOC and major element concentration in rivers sampled in three main permafrost zones (continuous, discontinuous and permafrost-free regions), during all seasons and of different watershed size class, was conducted using the non-parametric H-criterion Kruskal-Wallis test. First, we separated the watershed into four main classes encompassing all studied rivers (except the $\mathrm{Ob}$ ): $<100,100$ to 1000,1000 to 10000 , and $>10000 \mathrm{~km}^{2}$. We considered three main seasons in six different ranges of latitude (56 to $58^{\circ} \mathrm{N}, 58$ to $60^{\circ} \mathrm{N}, 60$ to $62^{\circ} \mathrm{N}, 62$ to $64^{\circ} \mathrm{N}, 64$ to $66^{\circ} \mathrm{N}$ and 66 to $68^{\circ} \mathrm{N}$ ). We checked for the variation in measured parameters of each watershed size as a function of latitude, separately in each season. In addition, a generalized assessment of the role of permafrost type and abundance on river water chemical composition was possible via separating all the sampled watersheds into three categories according to the permafrost distribution in the WSL: permafrost-free, discontinuous and continuous permafrost.

\section{Results}

Results of major element analysis in rivers are listed in Table $\mathrm{S} 1$ of the Supplement and the main results of statistical treatment are listed in Table S2. Based on the Kruskal-Wallis H statistics, the differences between the seasons and between different latitudes were found to be significantly higher ( $p$ level $<0.0001$ ) for most elements than the difference between watershed size classes, within each season and within each latitude range. This is illustrated for $\mathrm{pH}, \mathrm{DOC}, \mathrm{DIC}$ and $\delta^{13} \mathrm{C}_{\text {DIC }}$ in Figs. 2, 3, 4 and 5, respectively, which show the measured value as a function of latitude for different watershed classes, individually for each main season. Similar plots for major cations $(\mathrm{Ca}, \mathrm{Mg}, \mathrm{K})$ and $\mathrm{Si}$ are given in Supplement Figs. S1, S2, S3 and S4, respectively. The latitudinal coverage of October was too small to be presented in these figures; however, the October data of 12 rivers were used for statistical treatment and for assessing the permafrost impact. There is a clear and significant trend of concentration with latitude; the differences between different latitude ranges are significant at $p<0.0001$ for all elements, and at $p<0.05$ for $\mathrm{Si}$. The effect of the watershed size on river water chemical composition in summer, winter and spring is much smaller than that of latitude $(9<\mathrm{H}<12, p<0.05$ and $20<H<50$, $p<0.001$, respectively). Considering all rivers simultaneously, the effect of the season is clearly seen at $p<0.001$ for all elements except DOC; the latter, however, is also sta- 


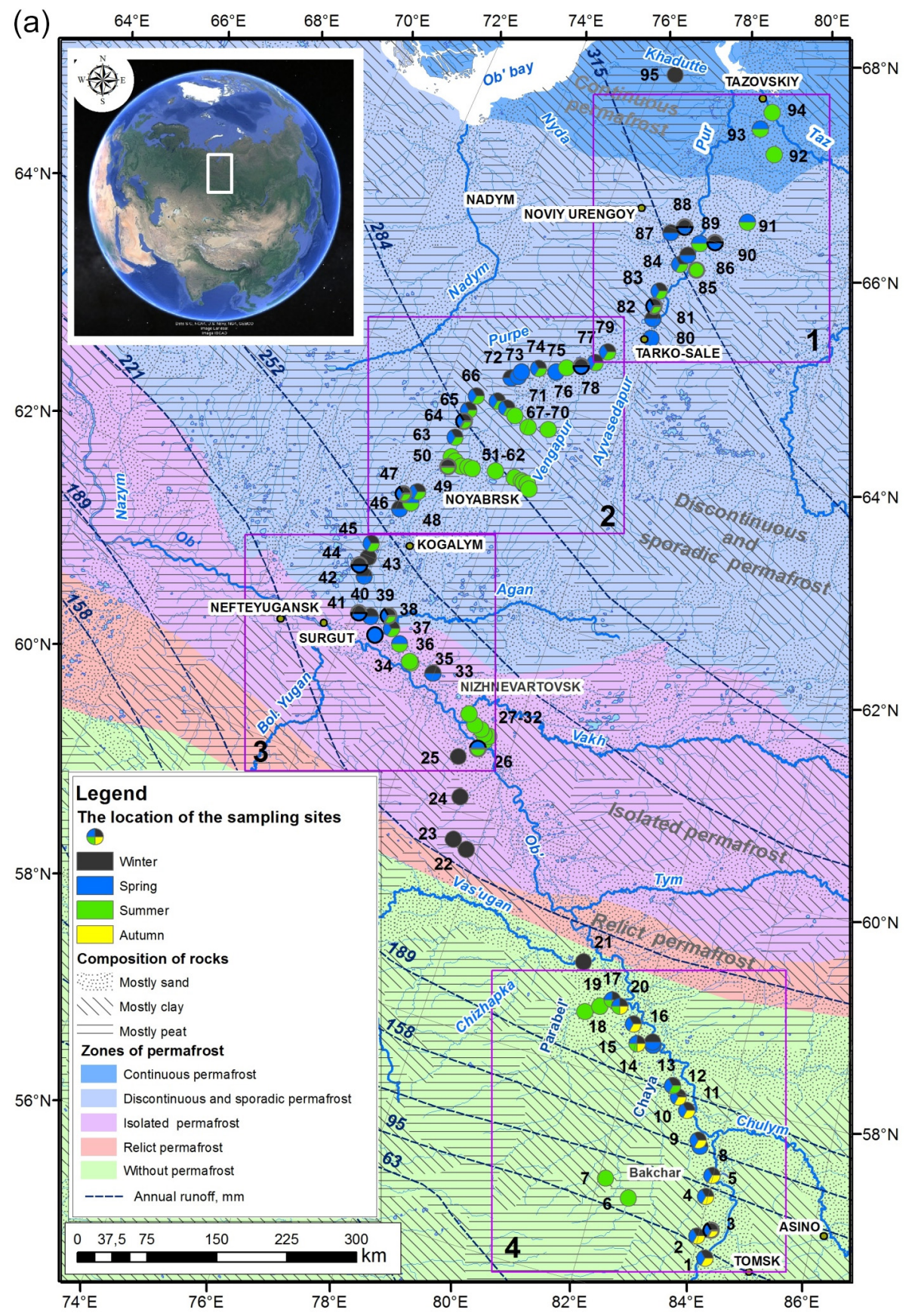

Figure 1.

tistically significant $(H=10.6, p=0.014)$. Considering the full data set of all seasons and watershed sizes, we distinguished three geographical zones in terms of the permafrost abundance: continuous, discontinuous and absent. For most river water parameters $(\mathrm{pH}, \mathrm{DIC}, \mathrm{DOC}$, major anions and cations) the differences between three zones are significant $(30<H<95, p$ level $<0.001)$. Si concentration exhibited lower but statistically significant differences between different zones $(H=9.5, p=0.0086)$.
Considering all seasons and watershed sizes revealed a significant decrease in $\mathrm{pH}, \mathrm{Ca}$ and $\mathrm{Mg}$ northward with the largest changes occurring at the beginning of discontinuous permafrost coverage (Fig. S5a, b and c in the Supplement, respectively). The DOC and DIC also decrease in concentration with the increase in the degree of permafrost coverage (Fig. S6a and b, respectively), whereas the isotopic composition of the DIC becomes progressively more negative northward (from ca. $-15 \%$ in the permafrost-free zone to -20 to 
(b) ${ }_{74: E}$
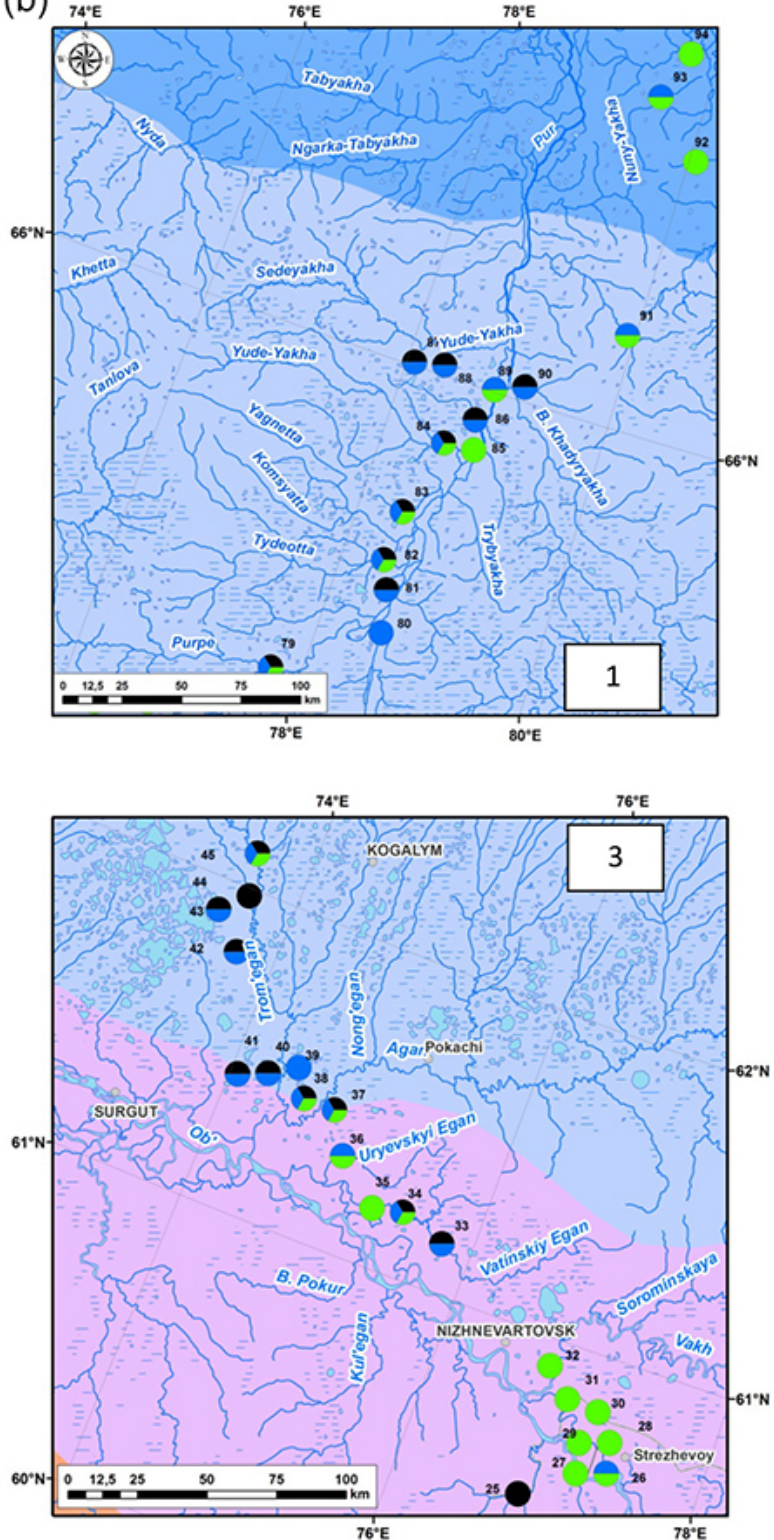
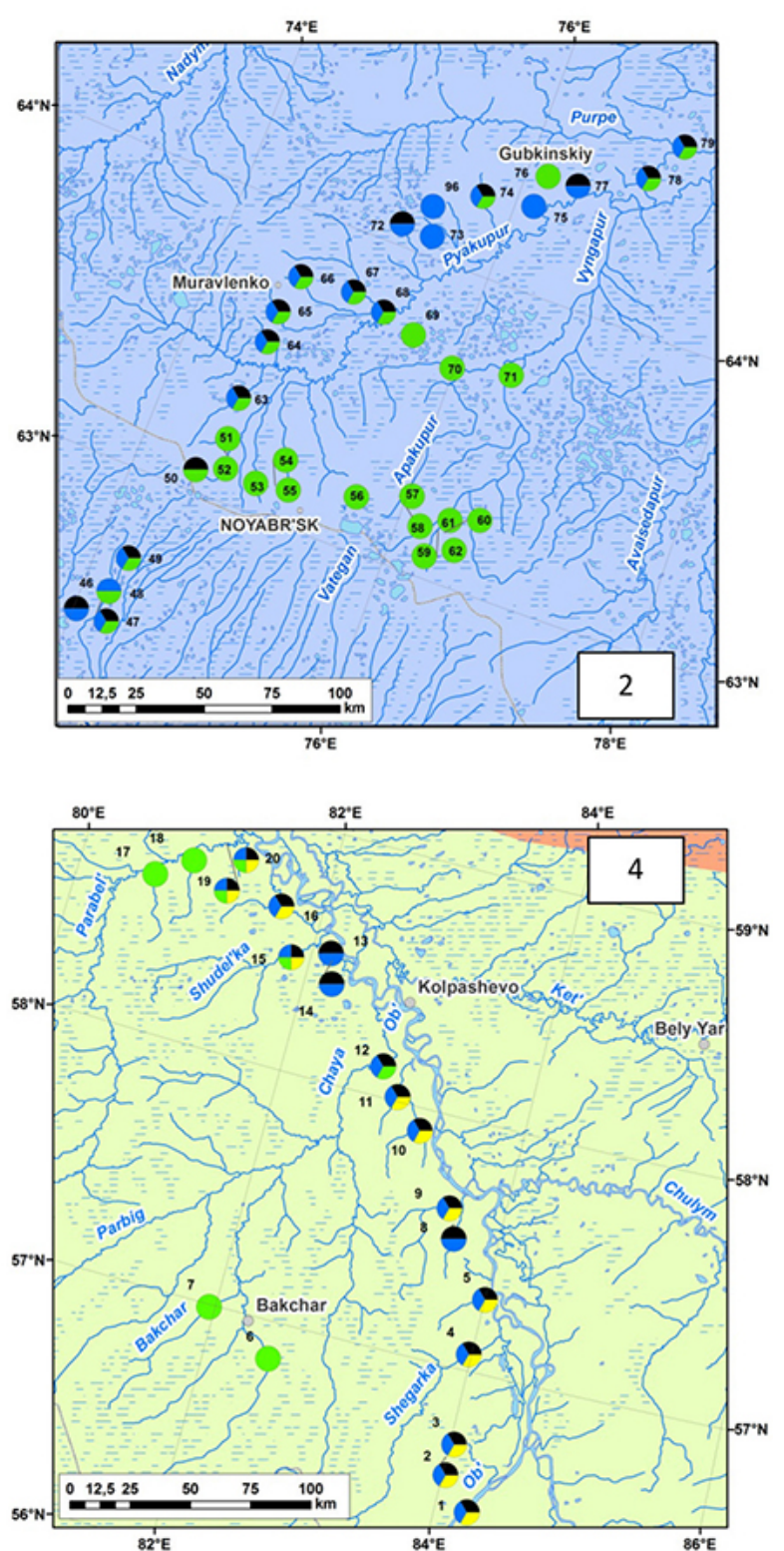

Figure 1. (a) Map of the study site with permafrost boundaries (Brown et al., 2002; http://portal.inter-map.com (NSIDC)), runoff contour lines (Nikitin and Zemtzov, 1986) and sampling points along the latitudinal transect of river basin of the Ob, Pur and Taz. The numbers of the sampling sites are listed in Table 1. (b) Detailed map of the four rectangles in (a).

$-25 \%$ in the continuous permafrost zone, Fig. S6c). In contrast, the effect of the permafrost on Si concentration is not clearly seen; the scatter of the data between different seasons and watersheds does not allow for any significant trend to be traced (not shown).

The optical properties of DOC remain essentially constant throughout the full range of watershed sizes, latitudes and seasons (Fig. S7). The largest variation in specific $\mathrm{UV}_{280 \mathrm{~nm}}$ absorbance occurred in winter, when several DOC-rich waters from the southern (permafrost-free) part of the WSL demonstrated quite a low concentration of aromatic (colored) compounds.

\section{Discussion}

\subsection{Effect of latitude (permafrost and vegetation) on major cation, Si and DIC mobilization from the soil profile and groundwater to the river}

From general knowledge of environmental control on carbon and major element fluxes in rivers of the Russian subarctic 

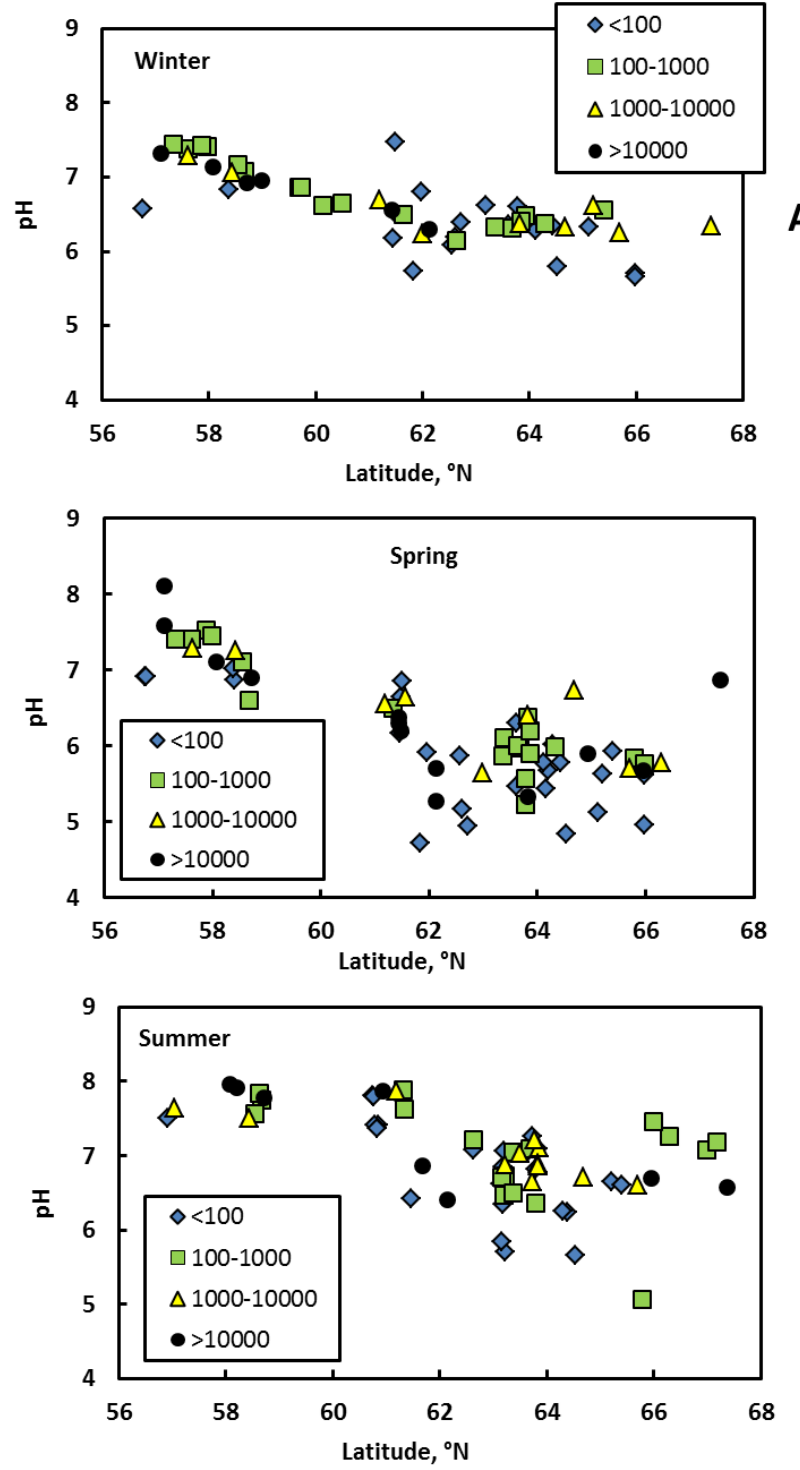

Figure 2. Decrease in river water $\mathrm{pH}$ with the increase in the latitude during winter (a), spring (b) and summer (c). The spring acid pulse is seen only in permafrost-affected rivers north of $62^{\circ} \mathrm{N}(\mathrm{b})$, and the scatter of the values is maximal during summer (c). The variability among different watershed sizes is smaller than that between the seasons and within the latitude gradient. Diamonds, squares, triangles and circles represent watersheds of size $<100,100$ to 1000 , 1000 to 10000 , and $>10000 \mathrm{~km}^{2}$, respectively.

(Prokushkin et al., 2011; Pokrovsky et al., 2012) and other boreal and subarctic regions (Laudon et al., 2004; Petrone et al., 2006; Walvoord and Striegl, 2007; Jantze et al., 2013; Giesler et al., 2014), we anticipate a decrease in most element concentrations, including DOC, northward regardless of the season and the river size in the WSL due to (1) a decrease in chemical weathering intensity with the temperature, well demonstrated for igneous rocks such as basalts (Dessert et al., 2003) and granites (Oliva et al., 2003); (2) a decrease

C
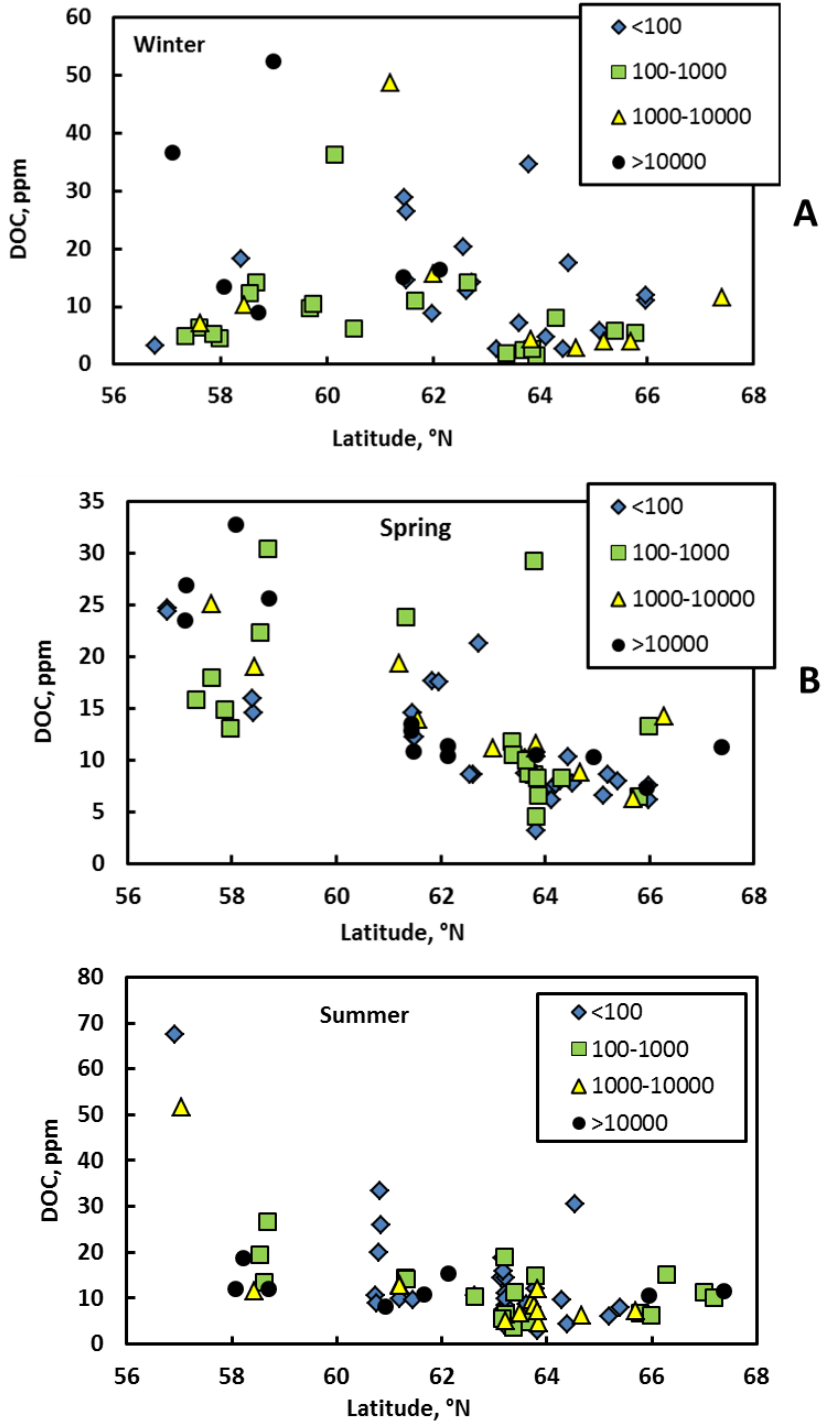

Figure 3. Decrease in DOC with latitude during winter (a), spring (b) and summer (c). The latitudinal trend is significant at $p<0.05$. Considering all seasons together, the differences between different watershed sizes are not statistically significant $(p>0.05)$. The symbols are the same as in Fig. 2.

in the thickness of peat deposits in total and the active soil (peat) layer in particular (Liss et al., 2001; Beilman et al., 2009; Stepanova et al., 2015, and references therein); (3) a decrease in plant biomass and related plant litter stock on the surface of the soils (Tyrtikov, 1979; Frey and Smith, 2007); (4) a shortening of the unfrozen period of the year; and (5) a decrease in the degree of groundwater feeding (Romanovsky, 1983; Nikitin and Zemtsov, 1986; Fotiev, 1991). The factors capable of enhancing element export fluxes in northern (permafrost-bearing) rivers relative to southern (permafrostfree) rivers of the WSL are (1) the decrease in dissolved organic matter (DOM) respiration by heterotrophs in the water and soil column and thus the increasing removal of al- 

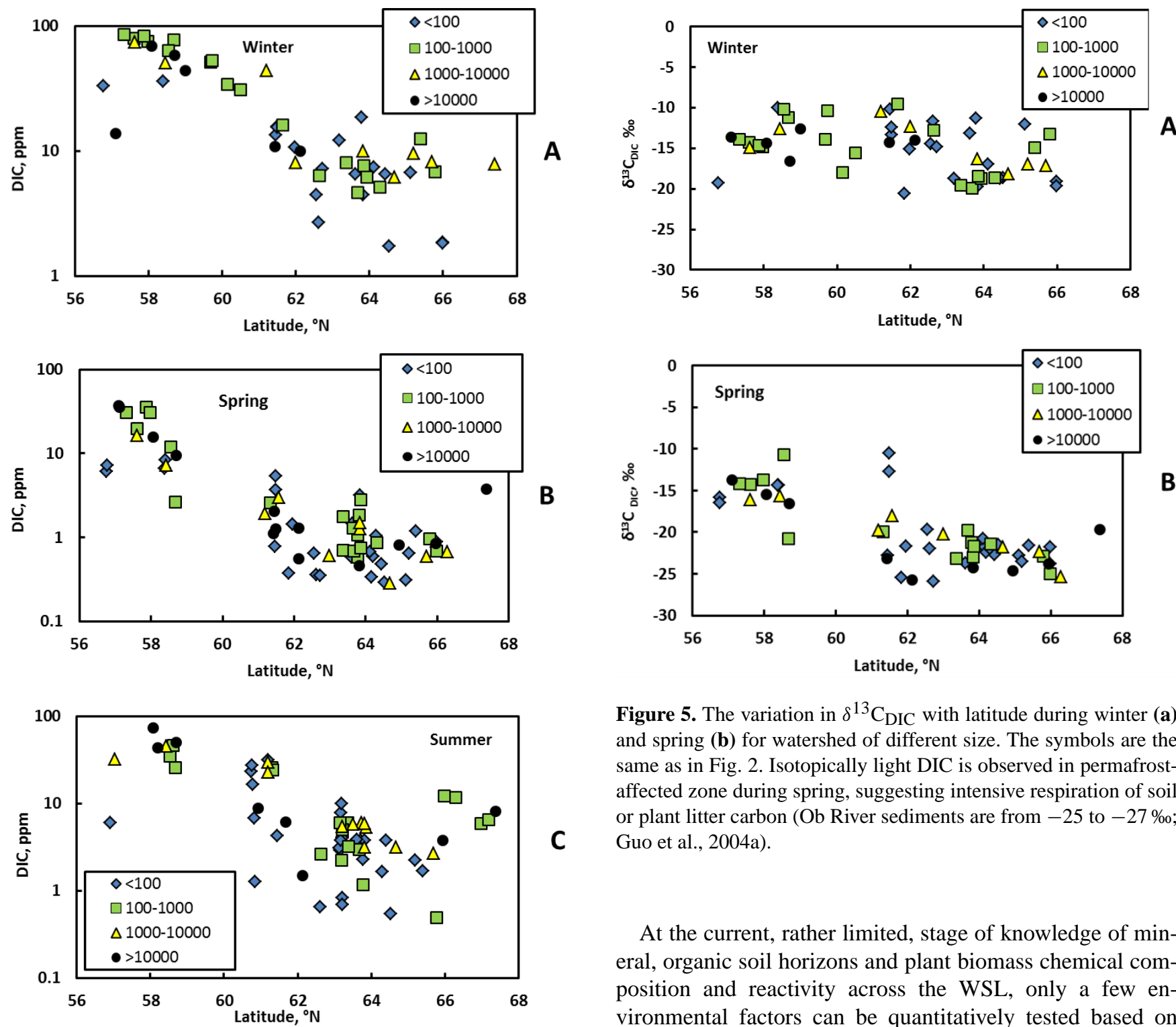

Figure 5. The variation in $\delta^{13} \mathrm{C}_{\text {DIC }}$ with latitude during winter (a) and spring (b) for watershed of different size. The symbols are the same as in Fig. 2. Isotopically light DIC is observed in permafrostaffected zone during spring, suggesting intensive respiration of soil or plant litter carbon (Ob River sediments are from -25 to $-27 \%$; Guo et al., 2004a).

Figure 4. Significant decrease in DIC with latitude during winter (a), spring (b) and summer (c). Note the logarithmic scale on concentration in all three plots. The symbols represent different size of the watershed; see Fig. 2.

lochthonous DOC from the soil to the river (Striegl et al., 2005); (2) the increase in DOC and related element leaching from plant litter and topsoil (Pokrovsky et al., 2005; Giesler et al., 2006; Fraysse et al., 2010) during more pronounced massive freshet event or summer high flow (Michel and Vaneverdingen, 1994; McClelland et al., 2006; White et al., 2007); (3) the decrease in DOM retention (adsorption) on the mineral soil horizon because clay horizon is typically frozen in the north (Kawahigashi et al., 2004); (4) the decrease in authigenic clay and allophane mineral formation in the soil horizons (Targulian, 1971).

At the current, rather limited, stage of knowledge of mineral, organic soil horizons and plant biomass chemical composition and reactivity across the WSL, only a few environmental factors can be quantitatively tested based on river water chemical analyses. In the case of the dominance of groundwater feeding of the river, the decrease in element concentrations from water-rock interaction whose transport is not limited by availability of $\mathrm{DOM}(\mathrm{Ca}, \mathrm{Mg}$, DIC) is expected to be most pronounced in winter, when the groundwater feeding is maximal (see Walvoord and Striegl, 2007, for the Yukon River basin example). Moreover, in the permafrost-bearing zone during winter baseflow, one should expect significant differences in element concentration in winter between small rivers (weakly or not affected by taliks) and large rivers (essentially fed by taliks), as is known from local geocryological conditions (Baulin et al., 1967; Romanovsky, 1983; Fotiev, 1989, 1991; Ivanov and Beshentsev, 2005). In spring, when the active layer is very thin and the majority of the soil column is frozen, the export from the watershed is dominated by surface flow and thus the difference in groundwater-related element concentration between (i) small and large rivers and (ii) north and 
south should be minimal. However, the abovementioned hypotheses are not supported by DIC, $\mathrm{Ca}$ and $\mathrm{Mg}$ concentrations observed in rivers (Figs. 4, S1 and S2). First, the DIC concentrations decrease between permafrost-free and discontinuous/continuous permafrost zones is a factor of $15 \pm 5$ in winter (Fig. 4a) and a factor of $60 \pm 10$ in spring (Fig. 4b). Similarly, the decrease in $\mathrm{Ca}$ and $\mathrm{Mg}$ concentrations between south of $59^{\circ} \mathrm{N}$ and $62-66^{\circ} \mathrm{N}$ zones is 10 -fold in winter and 20-30-fold in May. In fact, it is the spring period which exhibits the highest contrast in element concentrations between the south and the north. Second, for the latitude concentrations gradient from south to north, the relative DIC, $\mathrm{Ca}$ and $\mathrm{Mg}$ concentration change between large (1000-10000 and $\left.>10000 \mathrm{~km}^{2}\right)$ and small $\left(<100 \mathrm{~km}^{2}\right)$ rivers in winter is not statistically significant $(p>0.05)$.

However, a systematic decrease in Ca concentration in the WSL rivers northward (Figs. S1, S5b) is consistent with a general decrease in $\mathrm{Ca}$ concentration in soil ecosystems as illustrated in Fig. S8. An order-of-magnitude decrease in Ca concentration in mineral horizons of WSL peat columns occurred between 55 and $66^{\circ} \mathrm{N}$ (Stepanova et al., 2015). On a smaller scale, a 3-fold decrease in exchangeable Ca concentration in alluvial soils of the $\mathrm{Ob}$ Basin from 56 to $60^{\circ} \mathrm{N}$ was reported (Izerskaia et al., 2014). These observations confirm a strong control of lithology and soil weathering on Ca concentration in both deep and surface soil horizons and vegetation, which finally determines the extent of $\mathrm{Ca}$ transport via surface flux to the river.

North of $66^{\circ} \mathrm{N}$, concentrations of $\mathrm{Ca}, \mathrm{Mg}$ and sulfate increase relative to their concentration at $62-66^{\circ} \mathrm{N}$ of discontinuous permafrost zone. This is especially pronounced during the summer period (Figs. S1c, S2c). We do not exclude here the influence of marine sedimentary deposits containing salts in the deep part of the mineral soil profile below the peat layer. These deposits are described in the low reaches of Taz and Pur rivers, based on sedimentary cores extracted during extensive drilling of the territory (Liss et al., 2001). This influence, however, cannot be unequivocally evidenced because (i) DIC concentrations also increase in summer, north of $66^{\circ} \mathrm{N}$, although DIC is not likely to be affected by marine deposits, and (ii) chloride, an efficient marker of sea salts, is not increasing in the north (not shown).

The isotopic composition of DIC confirms the general features of DIC and cation concentration (Fig. 5). The groundwater feeding by taliks in winter is highly uniform over $10^{\circ}$ of latitude, with the value of $\delta^{13} \mathrm{C}_{\text {DIC }}$ being equal to $-15 \pm 5 \%$, reflecting both carbonate/silicate weathering and a buildup of $\mathrm{CO}_{2}$ with a stronger respiratory signal (Finlay, 2003; Striegl et al., 2001; Giesler et al., 2014; Rinta et al., 2015). During this period, the variability in $\delta^{13} \mathrm{C}_{\text {DIC }}$ is the highest in small $\left(<100 \mathrm{~km}^{2}\right)$ watersheds, but no trend of isotopic composition with latitude could be evidenced at $p<0.05$ (Fig. 5a). This isotopic signature is preserved in spring for southern $\left(<60^{\circ} \mathrm{N}\right)$ watersheds whereas in permafrost-affected regions, $\delta^{13} \mathrm{C}_{\text {DIC }}$ decreases to ca. -25 to $-20 \%$ regardless of the river size and the type and the abundance of the permafrost (Fig. 5b). Such low values in the permafrost-affected zone could no longer represent the influence of carbonate/silicate rock weathering by soil $\mathrm{CO}_{2}$ and likely reflect direct microbial processing of soil and sedimentary organic matter (Waldron et al., 2007; Giesler et al., 2013), with the DIC isotopic signature similar to that of organic carbon in western Siberian subarctic topsoil $(-26 \pm 2 \%$; Gentsch et al., 2015) and the Ob River organic sediments ( -25 to $-27 \%$; Guo et al., 2004a).

A plausible explanation for the $\delta^{13} C_{\text {DIC }}$ seasonal variation being mostly pronounced in the permafrost zone can be that microbial mineralization of dissolved organic carbon occurs most efficiently during the springtime, when significant amounts of fresh organic matter from ground vegetation are leached by melted snow. Higher bioavailability of vegetation leachates relative to more refractory soil humic and fulvic acids is known from studies in other temperate (van Hees et al., 2005) and boreal (Wickland et al., 2007) regions. The lack of $\delta^{13} \mathrm{C}_{\text {DIC }}$ decrease in spring relative to winter in the permafrost-free zone may stem from (i) significant input of the carbonate/silicate rock-hosted groundwaters during the full period of the year in the south or (ii) the different nature of DOM in the south, where the more refractory organic matter originated from peat leaching is less subjected to microbial processing compared to fresh vegetation leachates in the north, where the peat soil in spring is frozen. One has also take into account that the DIC concentrations in spring are a factor of 30 lower in the permafrost-bearing region relative to the permafrost-free region (Fig. 4b). As such, a relatively small input of microbially respired $\mathrm{CO}_{2}$ will be significantly more visible in the $\delta^{13} \mathrm{C}_{\mathrm{DIC}}$ value of the northern rivers compared to that of the southern rivers.

The variation in $\delta^{13} \mathrm{C}_{\mathrm{DIC}}$ along the permafrost and latitude gradient helps to better explain the origin of DIC in rivers in contrasting permafrost zones. Consistent with a progressive decrease in the groundwater feeding of rivers northward (Nikitin and Zemtzov, 1986; Frey et al., 2007b), we observe a distinct trend of $\delta^{13} \mathrm{C}_{\text {DIC }}$ with the latitude during the spring period, reflecting the shift of DIC origin from groundwater in the south to plant litter degradation and soil respiration in surface waters north of $62^{\circ} \mathrm{N}$ (Fig. 5b). In winter, the $\delta^{13} \mathrm{C}_{\mathrm{DIC}}$ is rather constant within the full latitudinal profile (Fig. 5a), confirming the dominant role of carbonate/silicate mineral weathering by atmospheric and soil $\mathrm{CO}_{2}$ dissolved in the groundwaters. Indeed, hydrological studies in the WSL revealed that the groundwater feeding of small $\left(<10000 \mathrm{~km}^{2}\right.$ watershed) rivers decreases from $20-30 \%$ in the discontinuous and sporadic/isolated part of the WSL to $3-6 \%$ in the northern, continuous permafrost zone (Novikov et al., 2009). These numbers agree with estimations based on Russian Hydrological Society (RHS) data of large western Siberian rivers (Nadym, Pur and Taz) and the left tributaries of the Yenisei River (Dubches, Elogyi and Turukhan; Nikitin and Zemtzov, 1986). According to more recent evaluations 
of Frey et al. (2007b), the groundwater contribution to summertime period river chemical composition ranges between 30 and $80 \%$ for the rivers located between 56 and $58^{\circ} \mathrm{N}$.

Consistent with these findings, the $\mathrm{pH}$ values of 7 to 7.5 in the southern rivers observed both in winter and spring (Fig. 2a, b) are indicative of carbonate/silicate rock input. The spring acid pulse, well established in other permafrostfree boreal regions (Buffam et al., 2007), is not at all pronounced in the south of the WSL but becomes clearly visible in the permafrost-affected, northern regions where the springtime $\mathrm{pH}$ decreases to $5 \pm 0.5$ (Fig. 2b). This illustrates the more important role of plant litter and moss leaching in the permafrost-bearing zone on solute export from the watershed. In addition, the dominance of sands north of $62^{\circ} \mathrm{N}$ (Liss et al., 2001) may allow low-molecular-weight (LMW) organic acids migrate to the river from the soil profile. In the southern, permafrost-free zone, the dominating clays underneath the peat can adsorb acidic LMW organic compounds and thus do not allow the acid pulse to be clearly visible.

The increase in $\mathrm{pH}$ in summer relative to the spring period is again less visible in the south than in the north (Fig. 2c) and may reflect the persisting role of bedrock dissolution as well as the change in the river feeding regime, from top soil and vegetation in the north to the peat soil column leaching in the south. The summertime increase in river water $\mathrm{pH}$ north of $60^{\circ} \mathrm{N}$, in the forest-tundra and tundra zone may be linked to (i) enhanced photosynthesis in rivers of the north due to better insolation and less forest shading and (ii) mobilization of DOM and other solutes from soil depressions rather than from watershed divides. The depressions are subjected to intense rinsing during the spring seasons, when the majority of soluble acidic compounds are flushed from the litter and $\mathrm{O}_{\mathrm{e}}$ horizon. These mechanisms are evidenced from studies of the hydrological balance of frozen bogs performed in the northern part of studied territory (Novikov et al., 2009). In contrast, the watershed divides contain significant amounts of organic litter and release organic acids only in spring, when they are covered by temporary ponds of melted snow (see Manasypov et al., 2015). This hydrological scheme of river water feeding is based on the seasonal multiannual observations on frozen bogs of the north of the WSL (Novikov et al., 2009), although the chemical nature of DOM mobilized from different parts of the watershed remains unknown.

The importance of plant litter and ground vegetation leaching as element sources in western Siberian rivers can be assessed from the comparison of $\mathrm{K}$ concentrations as a function of latitude during different seasons (Fig. S3). The most significant decrease in $\mathrm{K}$ concentration from the southern $\left(<59^{\circ} \mathrm{N}\right)$ to the northern $\left(61-67^{\circ} \mathrm{N}\right)$ watersheds occurs in spring, during intense plant litter leaching. Regardless of latitude, $\mathrm{K}$ concentration follows the order spring $>$ winter $>$ summer, with the highest concentrations, up to $2500 \mathrm{ppb}$, recorded in permafrost-free region. Given that the other cations, possibly originating from the water-mineral interaction at some depth, do not exhibit such high concentration in spring, we interpret the springtime $\mathrm{K}$ "pulse" as indicative of plant litter leaching in the productive taiga zone. This "pulse" is much less visible in the permafrost zone due to significantly lower biomass and primary productivity of forest-tundra and tundra biomes compared to the taiga of the WSL (Tyrtikov, 1979; Liss et al., 2001).

Despite significant variability in Si concentrations among rivers of various sizes across the latitude profile (Fig. S4), the concentrations in the permafrost zone are not lower than those in the south of the WSL. Results of a previous study of WSL rivers during summer show that $\mathrm{Si}$ concentrations are weakly dependent on latitude (Frey et al., 2007), as also confirmed in this work for the spring flood and winter baseflow period. Given that (i) the dominance of permafrost north of $64^{\circ} \mathrm{N}$ implies very low groundwater feeding (4 to $6 \%$ of the annual discharge; see Nikitin and Zemtsov, 1986; Novikov, 2009) and (ii) the upper part of the soil profile including its seasonally frozen and unfrozen parts is mostly peat rather than silicate mineral sediments, the role of groundwatersilicate rock interaction in Si supply to northern rivers should be quite low. Therefore, we hypothesize that elevated concentrations of $\mathrm{Si}$ in northern rivers are due to peat leaching and degradation. A depletion of $\mathrm{Si}$ in rivers of the southern part of the WSL may be due to Si retained by abundant bog and forest vegetation. This is consistent with the general setting of the WSL, recovering from the last glaciation (Liss et al., 2001), with contemporary peat accumulation in the south and old frozen peat thawing/degrading in the north.

\subsection{DOC concentration across a $1500 \mathrm{~km}$ latitude transect of variable permafrost coverage}

Results of organic carbon concentration in western Siberian rivers collected over various seasons of the year generally confirm the pioneering findings of Frey and Smith (2005). The strong statistically significant $(p<0.05)$ contrast in DOC concentration between permafrost-free, discontinuous and continuous permafrost zone persists over the course of the year and each season except probably winter (Figs. 3 and $\mathrm{S} 6 \mathrm{a})$. This difference is also seen in $\delta^{13} \mathrm{C}_{\mathrm{DIC}}$ values among all three zones (Fig. S6c), suggesting, on the annual scale, a more significant contribution of microbial processing of plant and soil organic carbon to $\mathrm{HCO}_{3}$ and $\mathrm{CO}_{2}$ of the river water in the permafrost-bearing zone compared to the permafrost-free zone.

In accordance with the conclusion reached by Frey and Smith (2005), the variation in hydrology may play a limited role in DOC variability and export from the watershed of WSL rivers. The gradient in DOC concentrations along the latitudal profile remains similar between spring flood and summer baseflow (Fig. 3b and c). Although the winter period does not exhibit such a clear difference between permafrostfree and permafrost-affected regions (Fig. 3a), the contribution of the winter discharge to the annual flux of DOC is be- 
tween 10 and $15 \%$ and as such does not significantly affect annual export of DOC from the watersheds.

In contrast, the gradient of organic carbon concentration along the latitudinal profile in spring will be mostly controlled by the difference in plant litter stock subjected to leaching by melted snow. As such, one would not expect any significant difference between large and small rivers at otherwise similar runoff, vegetation and bog coverage. This is partially confirmed by the similarity of the $U_{2} 280 \mathrm{~nm}-\mathrm{DOC}$ slope, corresponding to similar degree of DOM humification, among different seasons and latitudinal positions (Fig. S7). The uniform distribution of $\mathrm{UV}_{280}$ absorbance demonstrates that the main control of DOC by allochthonous (terrestrial) input from peat and/or ground vegetation leachates. The exceptions are the rivers Vasyugan (no. 21), Shegarka (no. 4) and Vatinsky Egan (no. 34), exhibiting low $\mathrm{UV}_{280 \mathrm{~nm}}$ at high [DOC] (Fig. S7). These rivers are potentially affected by oil production sites and may contain some uncolored products of hydrocarbon oxidation in the underground waters.

Overall, results on western Siberian rivers generally confirm the conclusion of Finlay et al. (2006) on (i) the lack of groundwater contribution to streamflow in arctic watersheds and (ii) that river DOC dynamics are driven essentially by processes occurring at the soil surface. However, we doubt the importance of large DOC pool production under very cold conditions with regard to the main reason for sustained high concentration of DOC at snowmelt suggested by Finlay et al. (2006). Indeed, the plant litter degradation in winter, even in the warmest scenario, is minimal and does not contribute significantly to annual litter leaching (Bokhorst et al., 2010, 2013). Instead, we suggest fast plant litter and ground vegetation leaching in spring, at the very beginning of the snow melt. Such a fast enrichment in DOC and colored organic compounds of surface water depressions, on the order of several hours, has been observed in the discontinuous permafrost zone in early June (Manasypov et al., 2015). Significant release of DOC and nutrients from flooded ground vegetation in the southern part of the WSL is also known (Vorovyev et al., 2015).

An unexpected result of the study of western Siberian watersheds is the lack of the enrichment in DOC of small headwater streams, in contrast to what has been reported for Scandinavian rivers and streams (Ågren et al., 2007, 2014, and references therein). In the WSL, especially in the northern, permafrost-affected zone, the small $\left(<100 \mathrm{~km}^{2}\right)$ streams yielded DOC concentrations that were not statistically higher $(p>0.05)$ than those of larger rivers, neither in spring flood nor in summer. A number of factors can be responsible for the observed difference between permafrost-free European and permafrost-bearing Siberian watersheds. In the north of western Siberia, the microbial processing of DOM in large rivers may be weakly pronounced. This is confirmed by the observation that the degree of light $\mathrm{C}$ isotope enrichment (lowering $\left.\delta^{13} \mathrm{C}_{\text {DIC }}\right)$ in spring is independent $(p>0.05)$ of the size of the river (Fig. 5b) and, correspondingly, of the water residence time on the watershed. According to Kawahigashi et al. (2004), the DOM in northern, permafrost-affected tributaries of the Yenisey River was significantly less biodegradable than that in southern tributaries. This may contribute to better preservation of DOM in the stream yielding its independence of the water travel time. Small watersheds of western Siberia exhibit a runoff and average slope very similar to that of the large rivers, given the very flat orographic context of the WSL. This contrasts with the mountain regions of Sweden and Alaska, where the headwater streams may exhibit higher runoff and thus higher export of the dissolved constituents. Finally, the riparian zone, very important for regulation DOC stock and export in small streams draining glacially formed terrain of NW Europe (Dick et al., 2015; Kuglerová, et al., 2014), is much less pronounced in western Siberia, where generally flat, frequently flooded areas dominate the watershed profile.

The elevated DOC concentrations in continuous permafrost zone, especially north of $67^{\circ} \mathrm{N}$ observed in the present study (Fig. 3b, c), are consistent with previous results showing that, for otherwise similar factors, the permafrost areas are a greater source of DOC than the areas with seasonal frost (Carey et al., 2003). In permafrost areas, meltwater travels through organic-rich layers in the form of so-called suprapermafrost flow, as opposed to areas without impermeable permafrost table. In the latter, the infiltration of organic-rich surface waters to the deep mineral layer and DOC sorption on clay minerals may occur, thus decreasing the overall export of DOC (see Smedberg et al., 2006, for discussion). Given the dominance of peat rather than minerals within the active (unfrozen) layers of soil profile, the difference between permafrost-free and permafrost-affected zones is even more accentuated in western Siberia.

A sketch of typical soil profiles of western Siberia in the permafrost-free and permafrost-bearing zone presenting DOC mobilization pathways from the soil to the river in the end of active period is shown in Fig. 6. The two cross sections shown in this figure are highly representative for two most contrasting cases of soil and watershed flux formation, corresponding to dark coniferous taiga in the permafrostfree zone and dwarf shrubs with green mosses of tundra and forest-tundra in frozen peatlands of continuous permafrost zone; both sites are located at the watershed divide. The detailed position of soil horizons and their attribution to FAO is based on available literature data (Tyrtikov, 1973, 1979; Liss et al., 2001; Pavlov and Moskalenko, 2002) and our recent investigations of the region (Loiko et al., 2015; Stepanova et al., 2015). We hypothesize that plant-litter- and topsoilderived DOC adsorbs on clay mineral horizons in the southern, permafrost-free and discontinuous/sporadic permafrost zone but lacks the interaction with minerals in the continuous permafrost zone. This assumption corroborates results found during another latitudinal river transect of Siberia, along the Yenisey River and its left tributaries draining peatlands of the WSL (Kawahigashi et al., 2004, 2006): the northern tribu- 


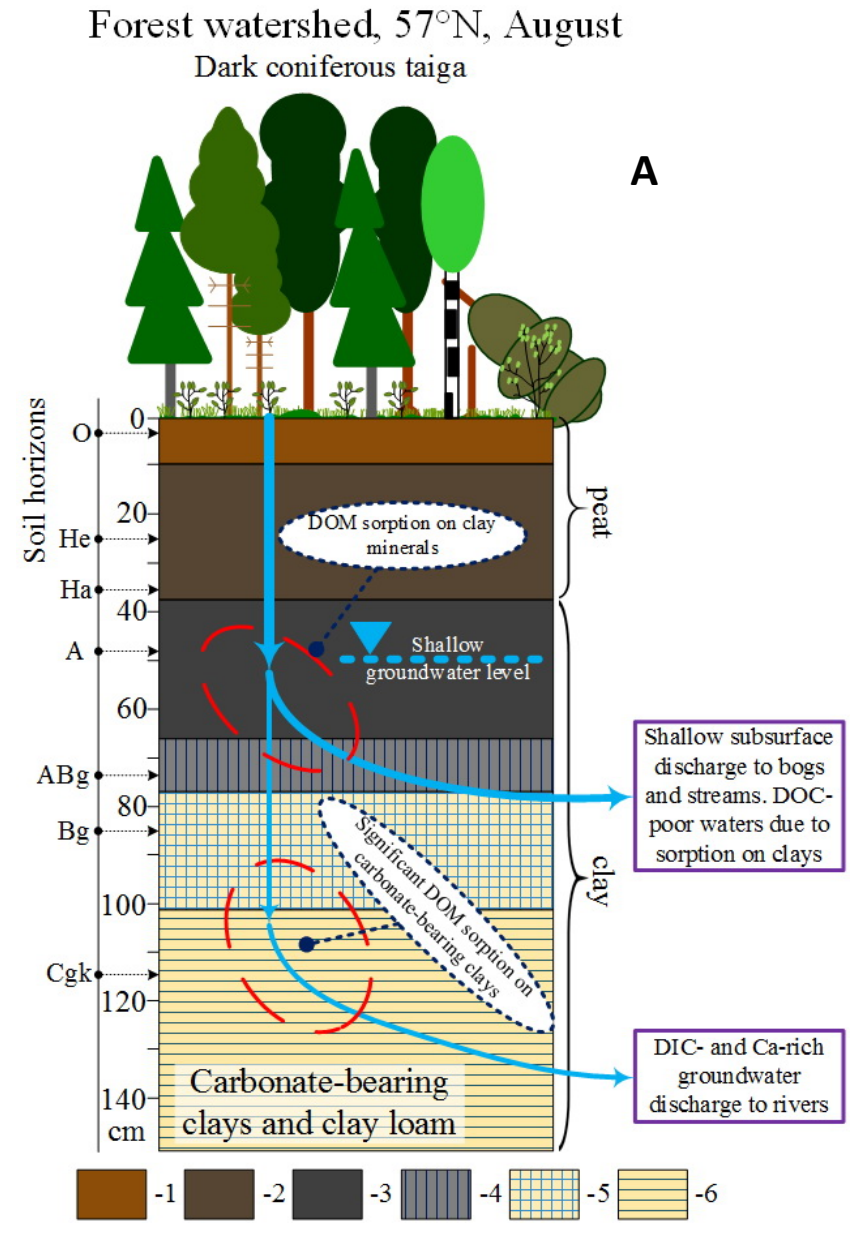

Figure 6.

taries exhibited significantly higher DOC concentrations than the southern tributaries of this river. Specifically, given the significant thickness of the peat even in the northernmost part of the WSL and the active layer thickness of $<50$ to $80 \mathrm{~cm}(30 \mathrm{~cm}$ on mounds and 80 to $150 \mathrm{~m}$ in troughs and depressions, Tyrtikov 1973, 1979; Baulin et al., 1967; Baulin, 1985; Khrenov, 2011; Novikov et al., 2009), even in the region of continuous permafrost development, peat soil interstitial solutions might not come in contact with the mineral soil horizon and thus will not decrease their DOC concentration during migration from the soil column to the river along the permafrost impermeable layer (Fig. 6).

Therefore, in the permafrost zone, the DOC export is strongly controlled by DOC residence time and the water travel pathway through organic topsoil and lichen, moss and litter leaching vs. peat and mineral layer leaching (Fig. 6b). In this case, it is only the thickness of the unfrozen peat and the local permafrost coverage that control the DOC export from the soil to the river. As a result, DOC concentration in the streams will be weakly dependent on the watershed size and seasons. It follows that DOC export from peat soils by
Frozen bog watershed $67^{\circ} \mathrm{N}$, August

Dwarf shrubs and green mosses

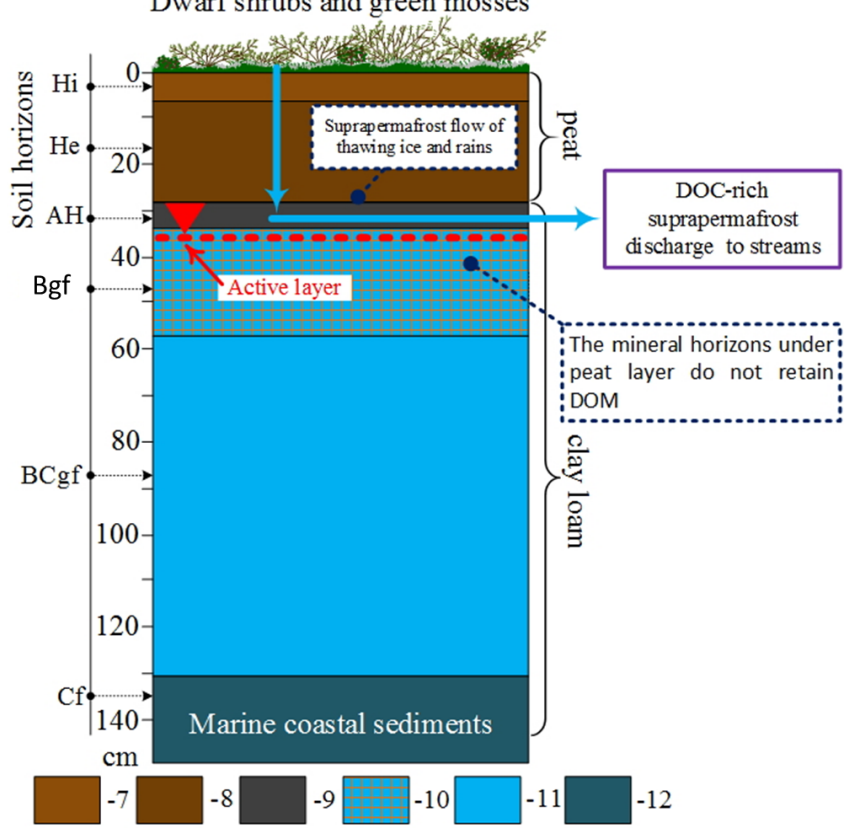

Figure 6. Scheme of DOC pathways within the soil profile and to the river. (a) In forest watershed of the south, permafrost-free zone $\left(57^{\circ} \mathrm{N}\right)$. Soil horizons (FAO, 2006): (1) O (Mor, forest litter), (2) medium-decomposed peat (He) transforming into strongly decomposed peat (Ha) in the bottom layer, (3) mollic humic horizon, (4) ABg surface horizons with stagnic properties, (5) Bg middle stagnic horizon, and (6) Cgk carbonate-bearing clays and clay loam. (b) DOC pathways in frozen bog peatlands of continuous permafrost $\left(67^{\circ} \mathrm{N}\right)$. Soil horizons (FAO, 2006): (7) weakly decomposed peat $(\mathrm{Hi}),(8)$ partially decomposed peat $(\mathrm{He}),(9)$ humic horizons $(\mathrm{AH}),(10)$ cryoturbated frozen stagnic horizon (Bgf), (11) frozen stagnic horizon (BCgf), and (12) sedimentary deposits (Cf). In the south, DOC is retained by clay, and deep in the soil profile by clay loam with carbonates. In the north, the active layer depth does not exceed the overall thickness of the peat and thus the leachates of ground vegetation and peat layer do not meet mineral horizons during their transit to the river.

medium-sized $\left(n \times 10000-n \times 100000 \mathrm{~km}^{2}\right)$ rivers located entirely in the permafrost zone may be higher than that of the larger rivers, crossing permafrost-free regions. This hypothesis is supported by available information on DOC yield by rivers of the WSL. Thus, the Taz $\left(s=150000 \mathrm{~km}^{2}\right)$, Pur $\left(112000 \mathrm{~km}^{2}\right)$ and Nadym rivers $\left(64000 \mathrm{~km}^{2}\right)$, entirely located in the discontinuous permafrost zone, exhibit 1.9, 2.1, and $4.4 \mathrm{t} \mathrm{km}^{-2} \mathrm{yr}^{-1}$ DOC yield, respectively (Gordeev et al., 1996, and calculated based on data of the RHS). This is significantly higher that the value suggested for the Ob River (1.2 $\mathrm{t} \mathrm{km}^{-2} \mathrm{yr}^{-1}$; Gordeev et al., 1996). 


\subsection{Possible evolution of chemical composition and fluxes of western Siberian rivers under climate change scenarios}

The most likely scenario of the climate change in western Siberia consists of shifting the permafrost boundary further north and increase in the active layer thickness (Pavlov and Moskalenko, 2002; Frey, 2003; Romanovsky et al., 2010; Vasiliev et al., 2011; Anisimov et al., 2013). The permafrost boundary change, equivalent to the northward shift of the river latitudes, may decrease the DOC concentrations of the most northern rivers by a maximum of 2 -fold due to the change of continuous to discontinuous permafrost. The thickness of the active layer is projected to increase by more than $30 \%$ during this century across the tundra area in the Northern Hemisphere (Anisimov et al., 2002; Stendel and Christensen, 2002; Dankers et al., 2011). In the WSL, this increase will be most dramatic in the north, where the peat deposits are thinner than those in the discontinuous permafrost zone (Botch et al., 1995; Liss et al., 2001; Novikov et al., 2009; Kremenetski et al., 2004). Assuming a shortterm (hundreds of years) scenario in the WSL, we hypothesize that the main consequences of this increase will be the involvement of upper clay horizon and sand/silts in water pathways within the soil profile. As a result, the DOC originating from the upper peat layer leaching and plant litter degradation will be retained on mineral surfaces and in the clay interlayers (Kaiser et al., 2007; Oosterwoud et al., 2010; Mergelov and Targulian, 2011; Gentsch et al., 2015). To which degree this change of water pathways in the soil column may affect the other dissolved components cannot be predicted. However, this effect for inorganic solutes is expected to be lower than that for DOC, given much lower affinity of $\mathrm{HCO}_{3}$, major cations and $\mathrm{Si}$ to clay surfaces and the lack of unweathered (primary) silicate rocks underneath the peat soil column. Nevertheless, the possibility of leaching of inorganic components from the mineral layers should be considered. For example, DOC export exceeded DIC export in a tributary of the Yukon River during high flow, whereas DIC predominated during low flow and the DIC yields increased with decreasing permafrost extent (Dornblaser and Striegl, 2015). Unfortunately, no time series on hydrochemistry of rivers of continuous permafrost development, north of $64^{\circ} \mathrm{N}$, are available to test the hypothesis of the impact of climate change on a possible decreasing DOC flux from frozen peatlands and the DOC/DIC change due to ongoing decrease in permafrost protection of the mineral layer from adsorbing DOC.

Important modifications linked to the climate change in boreal and subarctic zones concern the change of the hydrological regime (Karlsson et al., 2015), in particular the increase in the winter baseflow (Yang et al., 2004; Ye et al., 2009; Serreze et al., 2000) due to the increase in the groundwater feeding (Frey et al., 2007a, b; Walvoord and Striegl, 2007; Rowland et al., 2010; Walvoord et al., 2012), cou- pled with the increase in the overall precipitation and, consequently, water runoff (Peterson et al., 2002; McClelland et al., 2006). Here, we argue that the 10 to $30 \%$ modification in the annual runoff will be within the variation in the DOC and cation concentrations between watersheds of various sizes observed in the present study and as such will not significantly affect the export fluxes of river water constituents.

To which degree the ongoing DOC concentration and flux rise in rivers, linked to climate change and/or acidification as reported in western Europe and Canada (Worrall et al., 2004; Porcal et al., 2009) can be applied to the WSL is unknown. However, we did not observe any significant (i.e., $>30 \%$ ) change of DOC fluxes over past 30 to 40 years neither in the boreal non-permafrost pristine region of NW Russia (Severnaya Dvina River; Pokrovsky et al., 2010), nor in the Central Siberian, continuous permafrost rivers of the Yenisei Basin (Pokrovsky et al., 2005). Moreover, a decrease in DOC fluxes in the Yukon River was reported and suggested to be linked to enhanced mineralization of DOC by biota (Striegl et al., 2005). Note also that the more recent evaluation of the $\mathrm{Ob}$ River DOC discharge using flow-weighted concentration of $9.4 \mathrm{mg} \mathrm{L}^{-1}$ measured in 2003-2007 (Cooper et al., 2008) gives a flux of $1.3 \mathrm{tC} \mathrm{km}^{-2} \mathrm{yr}^{-1}$, well comparable with the earlier estimate of $1.2 \mathrm{tC} \mathrm{km}^{-2} \mathrm{yr}^{-1}$, based on the RHS data of 1950-1990 (Gordeev et al., 1996).

The increase in vegetation productivity reported for Arctic river basins (Sturm et al., 2001, Tape et al., 2006; Kirdyanov et al., 2012) will most likely proportionally increase the springtime $\mathrm{K}$ flux due to its leaching from plant litter but likely decrease the summertime $\mathrm{Si}$ flux, especially in the permafrost-bearing regions. The increase in vegetation density in the next decades to centuries may produce a transient uptake of Si by growing vegetation in the discontinuous permafrost zone during summer period. However, this potential decrease in Si export flux may be outweighed by the increasing release of $\mathrm{Si}$ from previously frozen mineral horizons and as such the overall modification of the Si concentration and riverine flux in the discontinuous-continuous permafrost zone may be smaller than that projected by simple latitudinal shift.

\section{Conclusions}

An unexpected result of the present study was rather low sensitivity of DOC, DIC, cations and Si concentration and fluxes to the size of the river. The season also played a secondary role in determining element concentration pattern. The most important governing parameter for concentrations of dissolved river water components was the latitude, allowing us to distinguish between permafrost-free, discontinuous and continuous permafrost regions. A northward decrease in DIC and dissolved cation $(\mathrm{Ca}, \mathrm{Mg})$ concentrations in the WSL rivers was mostly pronounced during spring flood. It was consistent with a general trend of soil cation (such as 
Ca) concentration decrease from the south to the north, reported for the peat, moss and mineral layer.

Both seasonal and latitudinal patterns of DOC and DIC concentrations in WSL rivers are consistent with previous observations that, in the continuous permafrost zone of frozen peat bogs, the underlining mineral layer is not reactive, being that it is protected by the permafrost, so that the major part of the active layer is located within the organic (peat) and not the mineral matrix. The variation in $\delta^{13} \mathrm{C}_{\mathrm{DIC}}$ along the permafrost/latitude gradient is consistent with a progressive decrease in the groundwater feeding of rivers northward, reflecting the shift of DIC origin from groundwater in the south to plant litter degradation and soil respiration in surface waters north of $62^{\circ} \mathrm{N}$. In winter, the $\delta^{13} \mathrm{C}_{\mathrm{DIC}}$ is rather constant within the full latitudinal profile, confirming the dominant role of carbonate/silicate mineral weathering by atmospheric and soil $\mathrm{CO}_{2}$ dissolved in the groundwaters.

Because the thickness of the unfrozen peat and local permafrost coverage essentially control the DOC export from the soil to the river, the DOC concentration in the streams is weakly dependent on the watershed size and seasons. It follows that DOC export from peat soils by medium-sized $\left(<100000 \mathrm{~km}^{2}\right)$ rivers located entirely in the permafrost zone may be higher than that of the larger rivers, crossing permafrost-free regions. Assuming a short-term (hundreds of years) climate warming scenario in the WSL, we hypothesize that the increase in the active layer thickness will bring about the involvement of upper clay horizon and sand/silts in water pathways within the soil profile. As a result, the DOC export in permafrost-affected watersheds may decrease, whereas the export of DIC and major cations will increase. Enhanced non-stationary uptake of $\mathrm{Si}$ by growing vegetation in the permafrost-bearing zone may attenuate the expected increase in its riverine concentration linked to progressive involvement of thawed mineral horizons.

\section{The Supplement related to this article is available online at doi:10.5194/bg-12-6301-2015-supplement.}

Author contributions. O. Pokrovsky designed the study and wrote the paper; R. Manasypov, I. Krickov, and S. Vorobyev performed sampling, analysis of major cations and their interpretation; S. Vorobyev and S. Kirpotin were responsible for the choice of sampling objects and statistical treatment; S. Loiko and S. Kulizhsky provided the background information on soil, peat, and permafrost active layer; L. Shirokova was in charge of DOC, DIC and anion measurements and their interpretation; B. Pokrovsky performed ${ }^{13} \mathrm{C}$ measurements and their interpretation; L. Kolesnichenko provided GIS-based interpretation, mapping and identification of river watersheds; S. Kopysov and V. Zemtsov performed all primary hydrological data collection, their analysis and interpretation. All 12 authors participated in field expeditions. Each co-author viewed and approved the final paper and contributed to writing the manuscript.
Acknowledgements. We acknowledge support from a BIO-GEOCLIM grant from the Ministry of Education and Science of the Russian Federation and Tomsk State University (no. 14.B25.31.0001) and partial support from RSF grant no. 15-17-10009 "Evolution of thermokarst ecosystems" awarded to L. Shirokova (25\%).

Edited by: J. Vonk

\section{References}

Ågren, A., Buffam, I., Jansson, M., and Laudon, H.: Importance of seasonality and small streams for the landscape regulation of dissolved organic carbon export, J. Geophys. Res., 112, G03003, doi:10.1029/2006JG000381, 2007.

Ågren, A. M., Buffam, I., Cooper, D. M., Tiwari, T., Evans, C. D., and Laudon, H.: Can the heterogeneity in stream dissolved organic carbon be explained by contributing landscape elements?, Biogeosciences, 11, 1199-1213, doi:10.5194/bg-11-1199-2014, 2014.

Anisimov, O. A., Shiklomanov, N. I., and Nelson, F. E.: Variability of seasonal thaw depth in permafrost regions: A stochastic modeling approach, Ecol. Model., 153, 217-227, 2002.

Anisimov, O., Kokorev, V., and Zhil'tsova, Y.: Temporal and spatial patterns of modern climatic warming: Case study of Northern Eurasia, Climatic Change, 118, 871-883, 2013.

Anisimova, N. P.: Cryohydrochemical Features of Permafrost Zone, Nauka, 1981 (in Russian).

Bagard, M. L., Chabaux, F., Pokrovsky, O. S., Prokushkin, A. S., Viers, J., Dupré, B., and Stille, P.: Seasonal variability of element fluxes in two Central Siberian rivers draining high latitude permafrost dominated areas, Geochim. Cosmochim. Acta, 75, 3335-3357, 2011.

Bagard, M. L., Schmitt, A. D., Chabaux, F., Pokrovsky, O. S., Viers, J., Stille, P., Labolle, F., and Prokushkin, A. S.: Biogeochemistry of stable $\mathrm{Ca}$ and radiogenic $\mathrm{Sr}$ isotopes in larch-covered permafrost-dominated watersheds of Central Siberia, Geochim. Cosmochim. Acta, 114, 169-187, 2013.

Baulin, V. V.: Permanently frozen rocks of oil and gaz producing regions of the USSR, Moscow, Nauka, 176 pp., 1985 (in Russian).

Baulin, V. V., Belopukhova, E. B., Dubikov, G. I., and Shmelev, L. M.: Geocryological conditions of western Siberia Lowland, Moscow, Nauka, 214 pp., 1967 (in Russian).

Beaulieu, E., Godderis, Y., Donnadieu, Y., Labat, D., and Roelandt, C.: High sensitivity of the continental-weathering carbon dioxide sink to future climate change, Nat. Clim. Change, 2, 346-349, 2012.

Beilman, D. W., MacDonald, G. M., Smith, L. C., and Reimer, P. J.: Carbon accumulation in peatlands of West Siberia over the last 2000 years, Global Biogeochem. Cy., 23, GB1012, doi:10.1029/2007GB003112, 2009.

Bokhorst, S., Bjerke, J. W., Melillo, J., Callaghan, T. V., and Phoenix, G. K.: Impacts of extreme winter warming events on litter decomposition in a sub-Arctic heathland, Soil Biol. Biochem., 42, 611-617, 2010.

Bokhorst, S., Metcalfe, D. B., and Wardle, D. A.: Reduction in snow depth negatively affects decomposers but impact on decomposition rates is substrate dependent, Soil Biol. Biochem., 62, 157164, 2013. 
Botch, M. S., Kobak, K. I., Vinson, T. S., and Kolchugina, T. P.: Carbon pools and accumulation in peatlands of the former Soviet Union, Global Biogeochem. Cy., 9, 37-46, 1995.

Brown, J., Ferrians Jr., O. J., Heginbottom, J. A., and Melnikov, E. S.: Circum-Arctic Map of Permafrost and Ground Ice Conditions, National Snow and Ice Data Center/World Data Center for Glaciology, Boulder, CO, USA, Digital media, 2002.

Buffam, I., Laudon, H., Temnerud, J., Mörth, C.-M., and Bishop, $\mathrm{K}$.: Landscape-scale variability of acidity and dissolved organic carbon during spring flood in a boreal stream network, J. Geophys. Res., 112, G01022, doi:10.1029/2006JG000218, 2007.

Carey, S. K.: Dissolved organic carbon fluxes in a discontinuous permafrost subarctic alpine catchment, Permafrost Periglac. Proc., 14, 161-171, 2003.

Cooper, L. W., McClelland, J. W., Holmes, R. M., Raymond, P. A., Gibson, J. J., Guay, C. K., and Peterson, B. J.: Flowweighted values of runoff tracers $\left(\delta^{18} \mathrm{O}\right.$, DOC, Ba, alkalinity) from the six largest Arctic rivers, Geophys. Res. Lett., 35, L18606, doi:10.1029/2008GL035007, 2008.

Dankers, R., Burke, E. J., and Price, J.: Simulation of permafrost and seasonal thaw depth in the JULES land surface scheme, The Cryosphere, 5, 773-790, doi:10.5194/tc-5-773-2011, 2011.

Dessert, C., Dupré, B., Gaillardet, J., Francois, L. M., and Allégre, C. J.: basalt weathering laws and the impact of basalt weathering on the global carbon cycle, Chem. Geol., 202, 257-273, 2003.

Dick, J. J., Tetzlaff, D., Birkel, C., and Soulsby, C.: Modelling landscape controls on dissolved organic carbon sources and fluxes to streams, Biogeochemistry, 122, 361-374, 2015.

Dittmar, T. and Kattner, G.: The biogeochemistry of the river and shelf ecosystem of the Arctic Ocean: a review, Mar. Chem., 83, 103-120, 2003.

Dornblaser, M. M. and Striegl, R. G.: Switching predominance of organic versus inorganic carbon exports from an intermediatesize subarctic watershed, Geophys. Res. Lett., 42, 386-394, 2015.

Engström, E., Rodushkin, I., Ingri, J., Baxter, D., Ecke, F., Österlund, H., and Öhlander, B.: Temporal isotopic variations of dissolved silicon in a pristine boreal river, Chem. Geol., 271, 142$152,2010$.

FAO, Guidelines for soil description, 4th Edn., Rome, FAO, 2006.

Feng, X. J., Vonk, J. E., van Dongen, B. E., Gustafsson, O., Semiletov, I. P., Dudarev, O. V., Wang, Z. H., Montlucon, D. B., Wacker, L., and Eglinton, T.I.: Differential mobilization of terrestrial carbon pools in Eurasian Arctic river basins, P. Natl. Acad. Sci. USA, 110, 14168-14173, 2013.

Finlay, J. C.: Controls of streamwater dissolved inorganic carbon dynamics in a forested watershed, Biogeochemistry, 62, 231$252,2003$.

Finlay, J., Neff, J., Zimov, S., Davydova, A., and Davydov, S.: Snowmelt dominance of dissolved organic carbon in high-latitude watersheds: Implications for characterization and flux of river DOC, Geophys. Res. Lett., 33, L10401, doi:10.1029/2006GL025754, 2006.

Fotiev, C. M.: Taliks and their formations (Taliki and zakonomernosti ix formirovanija), in: Geocryology of the USSR, Western Siberia, edited by: Ershov, E. D., Moscow, Nedra, 72-84, 1989 (in Russian).
Fotiev, C. M.: Formation of taliks of Western Siberia, in: Permanently frozen rocks and cryogenic processes, Moscow, Nauka, 71-78, 1991 (in Russian).

Fraysse, F., Pokrovsky, O. S., and Meunier, J.-D.: Experimental study of terrestrial plant litter interaction with aqueous solutions, Geochim. Cosmochim. Acta, 74, 70-84, 2010.

Frey, K. E. and McClelland, J. W.: Impacts of permafrost degradation on arctic river biogeochemistry, Hydrol. Process., 23, 169182, 2009.

Frey, K. E. and Smith, L. C.: Recent temperature and precipitation increases in West Siberia and their association with the Arctic Oscillation, Polar Res., 22, 287-300, 2003.

Frey, K. E. and Smith, L. C.: Amplified carbon release from vast West Siberian peatlands by 2100, Geophys. Res. Lett., 32, L09401, doi:10.1029/2004GL022025, 2005.

Frey, K. E. and Smith, L. C.: How well do we know northern land cover? Comparison of four global vegetation and wetland products with a new ground-truth database for West Siberia, Global Biogeochem. Cy., 21, GB1016, doi:10.1029/2006GB002706, 2007.

Frey, K. E., McClelland, J. W., Holmes, R. M., and Smith, L. C.: Impacts of climate warming and permafrost thaw on the riverine transport of nitrogen and phosphorus to the Kara Sea, J. Geophys. Res., 112, G04S58, doi:10.1029/2006JG000369, 2007a.

Frey, K. E., Siegel, D. I., and Smith, L. C.: Geochemistry of west Siberian streams and their potential response to permafrost degradation, Water Resour. Res., 43, W03406, doi:10.1029/2006WR004902, 2007b.

Fritz, P. and Fontes, J. C.: Handbook of environmental isotope geochemistry, v. 1, Elsevier, 1980.

Gaillardet, J., Millot, R., and Dupré, B.: Chemical denudation rates of the western Canadian orogenic belt: the Stikine terrane, Chem. Geol., 201, 257-279, 2003.

Gebhardt, A. C., Gaye-Haake, B., Unger, D., Lahajnar, N., and Ittekkot, V.: Recent particulate organic carbon and total suspended matter fluxes from the $\mathrm{Ob}$ and Yenisei Rivers into the Kara Sea (Siberia), Mar. Geol., 207, 225-245, 2004.

Gentsch, N., Mikutta, R., Alves, R. J. E., Barta, J., Capek, P., Gittel, A., Hugelius, G., Kuhry, P., Lashchinskiy, N., Palmtag, J., Richter, A., Šantrucková, H., Schnecker, J., Shibistova, O., Urich, T., Wild, B., and Guggenberger, G.: Storage and transformation of organic matter fractions in cryoturbated permafrost soils across the Siberian Arctic, Biogeosciences, 12, 4525-4542, doi:10.5194/bg-12-4525-2015, 2015.

Geological composition of the USSR, v. 1, Stratigraphy, ?oscow, Gostoptekhizdat, 588 pp., 1958 (in Russian).

Giesler, R., Högberg, M. N., Strobel, B. W., Richter, A., Nordgren, A., and Högberg, P.: Production of dissolved organic carbon and low-molecular weight organic acids in soil solution driven by recent tree photosynthate, Biogeochemistry, 84, 1-12, 2006.

Giesler, R., Mörth, C.-M., Karlsson, J., Lundin, E. J., Lyon, S. W., and Humborg, C.: Spatiotemporal variations of $p \mathrm{CO}_{2}$ and $\delta^{13} \mathrm{C}$-DIC in subarctic streams in northern Sweden, Global Biogeochem. Cy., 27, 176-186, 2013.

Giesler, R., Lyon, S. W., Mörth, C.-M., Karlsson, J., Karlsson, E. M., Jantze, E. J., Destouni, G., and Humborg, C.: Catchmentscale dissolved carbon concentrations and export estimates across six subarctic streams in northern Sweden, Biogeosciences, 11, 525-537, doi:10.5194/bg-11-525-2014, 2014. 
Gislason, S. R., Arnorsson, S., and Armannsson, H.: Chemical weathering of basalt as deduced from the composition of precipitation, rivers and rocks in Southwest Iceland: effect of runoff, age of rocks and vegetative/glacial cover, Am. J. Sci., 296, 837-907, 1996.

Gordeev, V. V. and Sidorov, I. S.: Concentrations of major elements and their outflow into the Laptev Sea by the Lena River, Mar. Chem., 43, 33-46, 1993.

Gordeev, V. V., Martin, J.-M., Sidorov, I. S., and Sidorova, M. V.: A reassessment of the Eurasian river input of water, sediment, major elements, and nutrients to the Arctic Ocean, Am. J. Sci., 296, 664-691, 1996.

Gordeev, V. V., Rachold, V., and Vlasova, I. E.: Geochemical behavior of major and trace elements in suspended particulate material of the Irtysh river, the main tributary of the $\mathrm{Ob}$ river, Siberia, Appl. Geochem., 19, 593-610, 2004.

Gruzdov, A. V. and Trofimov, V. T.: Abundance and temperature of permanently frozen and seasonally frozen rocks, In: Cryogenic composition and ice content of permanently frozen rocks of Western Siberian Plate, Moscow, Izd-vo Moscow State University, 29-57, 1980 (in Russian).

Guo, L., Semiletov, I., Gustafsson, O., Ingri, J., Andersson, P., Dudarev, O., and White, D.: Characterization of Siberian Arctic coastal sediments: Implications for terrestrial organic carbon export, Global Biogeochem. Cy., 18, GB1036, doi:10.1029/2003GB002087, 2004a.

Guo, L., Zhang, J. Z., and Guéguen, C.: Speciation and fluxes of nutrients (N, P, Si) from the upper Yukon River, Global Biogeochem. Cy., 18, GB1038, doi:10.1029/2003GB002152, 2004b.

Guo, L., Ping, C. L., and MacDonald, R.W.: Mobilization pathways of organic carbon from permafrost to Arctic rivers in a changing climate, Geophys. Res. Lett., 34, L13603, doi:10.1029/2007GL030689, 2007.

Holmes, R. M., Peterson, B. J., Gordeev, V. V., Zhulidov, A. V., Meybeck, M., Lammers, R. B., and Vörösmarty, C. J.: Flux of nutrients from Russian rivers to the Arctic Ocean: Can we establish a baseline against which to judge future changes? Water Resour. Res., 36, 2309-2320, 2000.

Holmes, R. M., Peterson, B. J., Zhulidov, A. V., Gordeev, V. V., Makkaveev, P. N., Stunzhas, P. A., Kosmenko, L. S., Köhler, G. H., and Shiklomanov, A. I.: Nutrient chemistry of the Ob' and Yenisey Rivers, Siberia: results from June 2000 expedition and evaluation of long-term data sets, Mar. Chem., 75, 219-227, 2001.

Holmes, R. M., McClelland, J. W., Peterson, B. J., Tank, S. E., Bulygina, E., Eglinton, T. I., Gordeev, V. V., Gurtovaya, T. Y., Raymond, P. A., Repeta, D. J., Staples, R., Striegl, R. G., Zhulidov, A. V., and Zimov, S. A.: Seasonal and annual fluxes of nutrients and organic matter from large rivers to the Arctic Ocean and surrounding seas, Estuar. Coast., 35, 369-382, 2012.

Ilina, S. M., Drozdova, O. Y., Lapitskiy, S. A., Alekhin, Y. V., Demin, V. V., Zavgorodnyaya, Y. A., Shirokova, L. S., Viers, J., and Pokrovsky, O. S.: Size fractionation and optical properties of dissolved organic matter in the continuum soil solution-bogriver and terminal lake of a boreal watershed, Org. Geochem., 66, 14-24, 2014.

Ivanov, Y. K. and Beshentsev, V. A.: Paleo-geographical aspects of formation of chemical composition of fresh underground waters in Yamalo-Nenetz region, Lithosphere, 4, 188-196, 2005.
Izerskaia, L. A., Vorobyev, S. N., Vorobyeva, T. E., Kolesnichenko, L. G., and Zakharchenko, A. V.: The concentration of $\mathrm{Mn}, \mathrm{Cu}$, $\mathrm{Zn}, \mathrm{Co}, \mathrm{B}, \mathrm{Sr}, \mathrm{Cd}$ and $\mathrm{Pb}$ in alluvial soils of the $\mathrm{Ob}$ River (foreststeppe, southern taiga and central taiga), Internat. J. Environ. Stud., 71, 691-697, 2014.

Jantze, E. J., Lyon, S. W., and Destouni, G.: Subsurface release and transport of dissolved carbon in a discontinuous permafrost region, Hydrol. Earth Syst. Sci., 17, 3827-3839, doi:10.5194/hess17-3827-2013, 2013.

Kaiser, C., Meyer, H., Biasi, C., Rusalimova, O., Barsukov, P., and Richter, A.: Conservation of soil organic matter through cryoturbation in arctic soils in Siberia, J. Geophys. Res., 112, 9-17, 2007.

Karlsson, J. M., Jaramillo, F., and Destouni, G.: Hydro-climatic and lake change patterns in Arctic permafrost and non-permafrost areas, J. Hydrol., 529, 134-145, 2015.

Kawahigashi, M., Kaiser, K., Kalbitz, K., Rodionov, A., and Guggenberger, G.: Dissolved organic matter in small streams along a gradient from discontinuous to continuous permafrost, Glob. Change Biol., 10, 1576-1586, 2004.

Kawahigashi, M., Kaiser, K., Rodionov, A., and Guggenberger, G.: Sorption of dissolved organic matter by mineral soils of the Siberian forest tundra, Glob. Change Biol., 12, 1868-1877, 2006.

Keller, K., Blum, J. D., and Kling, G. W.: Stream geochemistry as an indicator of increasing permafrost thaw depth in an arctic watershed, Chem. Geol., 273, 76-81, 2010.

Khrenov V. Y.: Soils of cryolithozone of western Siberia: Morphology, physico-chemical properties and geochemistry, Nauka, Moscow, 214 pp., 2011 (in Russian).

Kirdyanov, A. V., Hagedorn, F., Knorre, A. A., Fedotova, E. V., Vaganov, E. A., Naurzbaev, M. M., Moiseev, P. A., and Rigling, A.: 20th century tree-line advance and vegetation changes along an altitudinal transect in Putorana Mountains, northern Siberia, Boreas, 41, 56-67, 2012.

Kremenetski, K. V., Velichko, A. A., Borisova, O. K., MacDonald, G. M., Smith, L. C., Frey, K. E., and Orlova, L. A.: Peatlands of the West Siberian Lowlands: Current knowledge on zonation, carbon content, and Late Quaternary history, Quaternary Sci. Rev., 22, 703-723, 2003.

Kuglerová, L., Jansson, R., Ågren, A., Laudon, H., and MalmRenöfält, B.: Groundwater discharge creates hotspots of riparian plant species richness in a boreal forest stream network, Ecology, 95, 715-725, 2014.

Laudon, H., Köhler, S., and Buffam, I.: Seasonal TOC export from seven boreal catchments in northern Sweden, Aquat. Sci., 66, 223-230, 2004.

Liss, O. L., Abramova, L. I., Avetov, N. A., Berezina, N. A., Inisheva, L. I., Kurnishnikova, T. V., Sluka, Z. A., Tolpysheva, T. Yu., and Shvedchikova, N. K.: Wetland systems of West Siberia and their importance for nature conservation, Grif i K publisher, Tula, Russia, 584 pp., 2001 ISBN 5-8125-0150-5 (in Russian).

Lobbes, J. M., Fitznar, H. P., and Kattner, G.: Biogeochemical characteristics of dissolved and particulate organic matter in Russian rivers entering the Arctic Ocean, Geochim. Cosmochim. Acta, 64, 2973-2983, 2000.

Loiko, S. V., Geras'ko, L. I., Kulizhskii, S. P., Amelin, I. I., and Istigechev, G. I.: Soil cover patterns in the northern part of the area of aspen-fir taiga in the southeast of Western Siberia, Eurasian Soil Sci., 48, 359-372, 2015. 
Manasypov, R. M., Pokrovsky, O. S., Kirpotin, S. N., and Shirokova, L. S.: Thermokarst lake waters across the permafrost zones of western Siberia, The Cryosphere, 8, 1177-1193, doi:10.5194/tc-8-1177-2014, 2014.

Manasypov, R. M., Vorobyev, S. N., Loiko, S. V., Kritzkov, I. V., Shirokova, L. S., Shevchenko, V. P., Kirpotin, S. N., Kulizhsky, S. P., Kolesnichenko, L. G., Zemtzov, V. A., Sinkinov, V. V., and Pokrovsky, O. S.: Seasonal dynamics of organic carbon and metals in thermokarst lakes from the discontinuous permafrost zone of western Siberia, Biogeosciences, 12, 30093028, doi:10.5194/bg-12-3009-2015, 2015.

Mavromatis, V., Prokushkin, A. S., Pokrovsky, O. S., Viers, J., and Korets, M. A.: Magnesium isotopes in permafrost-dominated Central Siberian larch forest watersheds, Geochim. Cosmochim. Acta, 147, 76-89, 2014.

McClelland, J. W., Déry, S. J., Peterson, B. J., Holmes, R. M., and Wood, E. F.: A pan-Arctic evaluation of changes in river discharge during the latter half of the 20th century, Geophys. Res. Lett., 33, L06715, doi:10.1029/2006GL025753, 2006.

Mergelov, N. and Targulian, V.: Accumulation of organic matter in the mineral layers of permafrost-affected soils of coastal lowlands in East Siberia, Eurasian Soil Sci., 44, 249-260, 2011.

Michel, F. A. and Vaneverdingen, R. O.: Changes in hydrologic regimes in permafrost regions due to climate change, Permafrost Periglac. Proc., 5, 191-195, 1994.

Millot, R., Gaillardet, J., Dupré, B., and Allègre, C. J.: Northern latitude chemical weathering rates: Clues from the Mackenzie River Basin, Canada, Geochim. Cosmochim. Acta, 67, 13051329, 2003.

Moran, S. B. and Woods, W. L.: Cd, Cr, Cu, Ni and $\mathrm{Pb}$ in the water column and sediments of the Ob-Irtysh Rivers, Russia, Mar. Pollut. Bull., 35, 270-279, 1997.

Nikanorov, A. M., Bryzgalo, V. A., Kosmenko, L. S., and Reshetnyak, O. S.: The role of chemical river runoff in the anthropogenic transformation of the state of the aquatic environment in the Enisei mouth area, Water Resour., 37, 471-480, 2010a.

Nikanorov, A. M., Smirnov, M. P., and Klimenko, O. A.: Long-term trends in total and anthropogenic discharge of organic and biogenic substances by Russian rivers into the Arctic and Pacific Seas, Water Resour., 37, 361-371, 2010 b.

Nikitin, S. P. and Zemtsov, V. A.: The variability of hydrological parameters of western Siberia, Nauka, Novosibirsk, 204 pp., 1986 (in Russian).

Novikov, S. M., Moskvin, Y. P., Trofimov, S. A., Usova, L. I., Batuev, V. I., Tumanovskaya, S. M., Smirnova, V. P., Markov, M. L., Korotkevicth, A. E., and Potapova, T. M.: Hydrology of bog territories of the permafrost zone of western Siberia, BBM publ. House, St. Petersbourg, 535 pp., 2009 (in Russian).

Olefeldt, D. and Roulet, N. T.: Effects of permafrost and hydrology on the composition and transport of dissolved organic carbon in a subarctic peatland complex, J. Geophys. Res., 117, G01005, doi:10.1029/2011JG001819, 2012.

Olefeldt, D., Persson, A., and Turetsky, M. R.: Influence of the permafrost boundary on dissolved organic matter characteristics in rivers within the Boreal and Taiga plains of western Canada, Environ. Res. Lett., 9, 035005, doi:10.1088/1748-9326/9/3/035005, 2014.

Oliva, P., Viers, J., and Dupré, B.: Chemical weathering in granitic environments, Chem. Geol., 202, 225-256, 2003.
Oosterwoud, M. R., Temminghoff, E. J. M., and van der Zee, S. E. A. T. M.: Quantification of DOC concentrations in relation with soil properties of soils in tundra and taiga of Northern European Russia, Biogeosciences Discuss., 7, 3189-3226, doi:10.5194/bgd-7-3189-2010, 2010.

Pavlov, A. V. and Moskalenko, N. G.: The thermal regime of soils in the north of Western Siberia, Permafrost Periglac. Proc., 13, 43-51, 2002.

Peterson, B. J., Holmes, R. M., McClelland, J. W., Vorosmarty, C. J., Lammers, R. B., Shiklomanov, A. I., Shiklomanov, I. A., and Rahmstorf, S.: Increasing river discharge to the Arctic Ocean, Science, 298, 2171-2173, 2002.

Petrone, K. C., Jones, J. B., Hinzman, L. D., and Boone, R. D.: Seasonal export of carbon, nitrogen, and major solutes from Alaskan catchments with discontinuous permafrost, J. Geophys. Res., 111, G02020, doi:10.1029/2005JG000055, 2006.

Pokrovsky, O. S., Schott, J., Kudryavtzev, D. I., and Dupré, B.: Basalts weathering in Central Siberia under permafrost conditions, Geochim. Cosmochim. Acta, 69, 5659-5680, 2005.

Pokrovsky, O. S., Viers, J., Shirokova, L. S., Shevchenko, V. P., Filipov, A. S., and Dupré, B.: Dissolved, suspended, and colloidal fluxes of organic carbon, major and trace elements in Severnaya Dvina River and its tributary, Chem. Geol., 273, 136-149, 2010.

Pokrovsky, O. S., Viers, J., Dupré, B., Chabaux, F., Gaillardet, J., Audry, S., Prokushkin, A. S., Shirokova, L. S., Kirpotin, S. N., Lapitsky, S. A., and Shevchenko, V. P.: Biogeochemistry of carbon, major and trace elements in watersheds of Northern Eurasia drained to the Arctic Ocean: The change of fluxes, sources and mechanisms under the climate warming prospective, C. R. Geosci., 344, 663-677, 2012.

Pokrovsky, O. S., Reynolds, B. C., Prokushkin, A. S., Schott, J., and Viers, J.: Silicon isotope variations in Central Siberian rivers during basalt weathering in permafrost-dominated larch forests, Chem. Geol., 355, 103-116, 2013a.

Pokrovsky, O. S., Shirokova, L. S., Kirpotin, S. N., Kulizhsky, S. P., and Vorobiev, S. N.: Impact of western Siberia heat wave 2012 on greenhouse gases and trace metal concentration in thaw lakes of discontinuous permafrost zone, Biogeosciences, 10, 5349-5365, doi:10.5194/bg-10-5349-2013, 2013 b.

Porcal, P., Koprivnjak, J.-F., Molot, L. A., and Dillon, P. J.: Humic substaces - part 7: the biogeochemistry of dissolved organic carbon and its interactions with climate change, Environ. Sci. Pollut. R., 16, 714-726, 2009.

Prokushkin, A. S., Pokrovsky, O. S., Shirokova, L. S., Korets, M. A., Viers, J., Prokushkin, S. G., Amon, R., Guggenberger, G., and McDowell, W. H.: Sources and export fluxes of dissolved carbon in rivers draining larch-dominated basins of the Central Siberian Plateau, Environ. Res. Lett., 6, 45212, doi:10.1088/1748-9326/6/4/045212, 2011.

Rember, R. D. and Trefry, J. H.: Increased concentrations of dissolved trace metals and organic carbon during snowmelt in rivers of the Alaskan Arctic, Geochim. Cosmochim. Ac., 68, 477-489, 2004.

Rinta, P., Bastviken, D., van Hardenbroek, M., Kankaala, P., Leuenberger, M., Schilder, J., Stötter, T., and Heiri, O.: An inter-regional assessment of concentrations and $\delta^{13} \mathrm{C}$ values of methane and dissolved inorganic carbon in small European lakes, Aquat Sci., 77, 667-680, 2015. 
Romanovsky, N. N.: Underground waters of the cryolithozone, Moscow, Moscow State University Publ. House, 232 pp., 1983.

Romanovsky, V. E., Drozdov, D. S. Oberman, N. G., Malkova G. V., Kholodov A. L., Marchenko, S. S., Moskalenko, N. G., Sergeev D. O., Ukraintseva, N. G., Abramov A. A., Gilichinsky, D. A., and Vasiliev, A. A.: Thermal State of Permafrost in Russia, Permafrost Periglacial Proc., 21, 136-155, 2010.

Serreze, M. C., Walsh, J. E., Chapin, E., Osterkamp, T., Dyugerov, M., Romanovsky, V., Oechel, W. C., Morison, J., Zhang, T., and Barry, R. G.: Observation evidence of recent change in the northern high-latitude environment, Climatic Change, 46, 159-207, 2000.

Shirokova, L. S., Pokrovsky, O. S., Kirpotin, S. N., Desmukh, C., Pokrovsky, B. G., Audry, S., and Viers, J.: Biogeochemistry of organic carbon, $\mathrm{CO}_{2}, \mathrm{CH}_{4}$, and trace elements in thermokarst water bodies in discontinuous permafrost zones of Western Siberia, Biogeochemistry, 113, 573-593, 2013.

Smedberg, E., Mörth, C. M., Swaney, D. P., and Humborg, C.: Modeling hydrology and silicon-carbon interactions in taiga and tundra biomes from a landscape perspective: Implications for global warming feedback, Global Biogeochem. Cy., 20, GB2014, doi:10.1029/2005GB002567, 2006.

Smith, L. C., Macdonald, G. M., Velichko, A. A., Beilman, D. W., Borisova, O. K., Frey, K. E., Kremenetsky, K. V., and Sheng, Y.: Siberian peatlands as a net carbon sink and global methane source since the early Holocene, Science, 303, 353-356, 2004.

Stendel, M. and Christensen, J. H.: Impact of global warming on permafrost conditions in a coupled GCM, Geophys. Res. Lett., 29, 10-1-10-4, 2002.

Stepanova, V. M., Pokrovsky, O. S., Viers, J., MironychevaTokareva, N. P. Kosykh, N. P., and Vishnyakova, E. K.: Major and trace elements in peat profiles in Western Siberia: impact of the landscape context, latitude and permafrost coverage, Appl. Geochem., 53, 53-70, 2015.

Striegl, R. B., Kortelainen, P., Chanton, J. P., Wickland, K. P., Bugna, G. C., and Rantakari, M.: Carbon dioxide partial pressure and ${ }^{13} \mathrm{C}$ content of north temperate and boreal lakes at spring ice melt, Limnol. Oceanogr., 46, 941-945, 2001.

Striegl, R. G., Aiken, G. R., Dornblaser, M. M., Raymond, P. A., and Wickland, K. P.: A decrease in discharge-normalized DOC export by the Yukon River during summer through autumn, Geophys. Res. Lett., 32, L21413, doi:10.1029/2005GL024413, 2005.

Sturm, M., Racine, C., and Tape, K.: Increasing shrub abundance in the Arctic, Nature, 411, 546-547, 2001.

Tank, S. E., Raymond, P. A., Striegl, R. G., McClelland, J. W., Holmes, R. M., Fiske, G. J., and Peterson, B. J.: A land-to-ocean perspective on the magnitude, source and implication of DIC flux from major Arctic rivers to the Arctic Ocean, Global Biogeochem. Cy., 26, GB4018, doi:10.1029/2011GB004192, 2012a.

Tank, S. E., Frey, K. E., Striegl, R. G., Raymond, P. A., Holmes, R. M., McClelland, J. W., and Peterson, B. J.: Landscapelevel controls on dissolved carbon flux from diverse catchments of the circumboreal, Global Biogeochem. Cy., 26, GB0E02, doi:10.1029/2012GB004299, 2012b.

Tape, K., Sturm, M., and Racine, C.: The evidence for shrub expansion in Northern Alaska and the Pan-Arctic, Glob. Change Biol., 12, 686-702, 2006.
Targulian, V. O.: Soil Formation and Weathering in Cold Humid Regions (On Massive-Crystalline and Sandy Polymictic Rocks), Nauka, Moscow, 1971 (in Russian).

Tyrtikov, A. P.: Thawing of soils in tundra of western Siberia, in: Natural environment of western Siberia, edited by: Popov, A. I. Issue 3, Izd-vo MG, Moscow, 160-169, 1973 (in Russian).

Tyrtikov, A. P.: Dynamics of vegetation coverage and permafrost development in western Siberia, Moscow, Nauka, 114 pp., 1979 (in Russian).

van Hees, P. A. W., Jones, D. L., Finlay, R., Godbold, D. L., and Lundstrom, U. S.: The carbon we do not see - the impact of low molecular weight compounds on carbon dynamics and respiration in forest soils: a review, Soil Biol. Biochem., 37, 1-13, 2005.

Vasiliev, A. A., Streletskaya, I. D., Shirokov, R. S., and Oblogov, G. E.: Evolution of cryolithozone of coastal zone of western Yamal during climate change, Kriosfera Zemli, 2, 56-64, 2011 (in Russian).

Vorobyev, S. N., Pokrovsky, O. S., Kirpotin, S. N., Kolesnichenko, L. G., Shirokova, L. S., and Manasypov, R. M.: Flood zone biogeochemistry of the Ob' River middle course, Appl. Geochem., 63, 133-145, 2015.

Voronkov, P. P., Sokolova, O. K., Zubareva, V. I., and Naidenova, V. I.: Hydrochemical features of local discharge during spring flood from the soil coverage of European territory of the USSR, Trudy GGI (Proceedings of State Hydrological Institute), 137, 3-57, 1966 (in Russian).

Voss, B. M., Peucker-Ehrenbrink, B., Eglinton, T. I., Spencer, R. G. M., Bulygina, E., Galy, V., Lamborg, C. H., Ganguli, P. M., Montluçon, D. B., Marsh, S., Gillies, S. L., Fanslau, J., Epp, A., and Luymes, R.: Seasonal hydrology drives rapid shifts in the flux and composition of dissolved and particulate organic carbon and major and trace ions in the Fraser River, Canada, Biogeosciences, 12, 5597-5618, doi:10.5194/bg-12-5597-2015, 2015.

Waldron, S., Scott, M. E., and Soulsby, C.: Stable isotope analysis reveals lower-order river dissolved inorganic carbon pools are highly dynamic, Environ. Sci. Technol., 41, 6156-6162, doi:10.1021/es0706089, 2007.

Walvoord, M. A. and Striegl, R. G.: Increased groundwater to stream discharge from permafrost thawing in the Yukon River basin: Potential impacts on lateral export of carbon and nitrogen, J. Geophys. Res., 34, L12402, doi:10.1029/2007GL030216, 2007.

Walvoord, M. A., Voss, C. I., and Wellman, T. P.: Influence of permafrost distribution on groundwater flow in the context of climate-driven permafrost thaw: Example from Yukon Flats Basin, Alaska, United States, Water Res. Research, 48, W07524, doi:10.1029/2011WR011595, 2012.

White, A. F. and Blum, A. E.: Effects of climate on chemical weathering in watersheds, Geochim. Cosmochim. Ac., 59, 1729-1747, 1995.

White, D., Hinzman, L., Alessa, L., Cassano, J., Chambers, M., Falkner, K., Francis, J., Gutowski Jr., W. J., Holland, M., Holmes, R. M., Huntington, H., Kane, D., Kliskey, A., Lee, C., McClelland, J., Peterson, B., Rupp, T. S., Straneo, F., Steele, M., Woodgate, R., Yang, D., Yoshikawa, K., and Zhang, T.: The arctic freshwater system: Changes and impacts, J. Geophys. Res., 112, G04S54, doi:10.1029/2006JG000353, 2007. 
Wickland, K. P., Neff, J. C., and Aiken, G. R.: Dissolved organic carbon in Alaskan boreal forest: sources, chemical characteristics, and biodegradability, Ecosystems, 10, 1323-1340, 2007.

Worrall, F., Harriman, R., Evans, C. D., Watts, C. D., Adamson, J., Neal, C., Tipping, E., Burt, T., Grieve, I., Monteith, D., Naden, P. S., Nisbet, T., Reynolds, B., and Stevens, P.: Trends in dissolved organic carbon in UK rivers and lakes, Biogeochemistry, 70, 369-402, 2004.

Yang, D., Ye, B., and Shiklomanov, A.: Discharge characteristics and changes over the $\mathrm{Ob}$ River watershed in Siberia, J. Hydrometeorol., 5, 595-610, 2004.

Ye, B., Yang, D., Zhang, Z., and Kane, D. L.: Variation of hydrological regime with permafrost coverage over Lena basin in Siberia, J. Geophys. Res., 114, D07102, doi:10.1029/2008JD010537, 2009.

Yeghicheyan, D., Bossy, C., Bouhnik Le Coz, M., Douchet, Ch., Granier, G., Heimburger, A., Lacan, F., Lanzanova, A., Rousseau, T. C. C., Seidel, J.-L., Tharaud, M., Candaudap, F., Chmeleff, J., Cloquet, C., Delpoux, S., Labatut, M., Losno, R., Pradoux, C., Sivry, Y., and Sonke, J. E.: A Compilation of Silicon, Rare Earth Element and Twenty-One other Trace Element Concentrations in the Natural River Water Reference Material SLRS-5 (NRC-CNRC), Geostand. Geoanal. Res., 37, 449-467, 2013.
Zakharova, E. A., Pokrovsky, O. S., Dupré, B., and Zaslavskaya, M. B.: Chemical weathering of silicate rocks in Aldan Shield and Baikal Uplift: insights from long-term seasonal measurements of solute fluxes in rivers, Chem. Geol., 214, 223-248, 2005.

Zakharova, E. A., Pokrovsky, O. S., Dupré, B., Gaillardet, J., and Efimova, L.: Chemical weathering of silicate rocks in Karelia region and Kola peninsula, NW Russia: Assessing the effect of rock composition, wetlands and vegetation, Chem. Geol., 242, 255-277, 2007.

Zakharova, E. A., Kouraev, A. V., Rémy, F., Zemtsov, V. A., and Kirpotin, S. N.: Seasonal variability of the Western Siberia wetlands from satellite radar altimetry, J. Hydrol., 512, 366-378, 2014. 